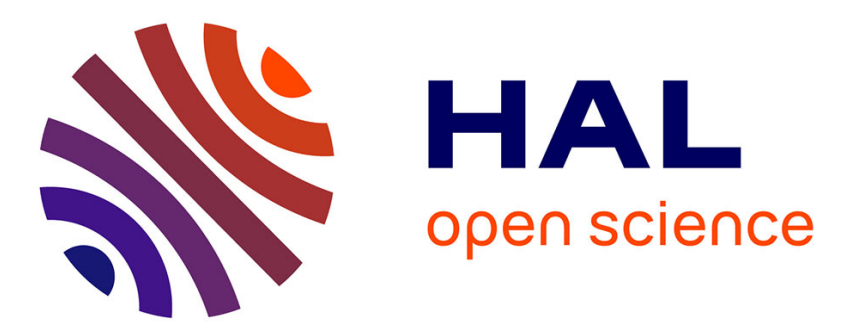

\title{
Solvent-free synthesis and properties of functionalized hydrazines and bishydrazines as energetic ingredients for propulsion applications
}

John Eymann, A Dhenain, L Joucla, G Jacob, Emmanuel Lacote, Chaza Darwich

\section{To cite this version:}

John Eymann, A Dhenain, L Joucla, G Jacob, Emmanuel Lacote, et al.. Solvent-free synthesis and properties of functionalized hydrazines and bishydrazines as energetic ingredients for propulsion applications. Chemistry - An Asian Journal, In press, 10.1002/asia.202001084R2 . hal-02975492

\section{HAL Id: hal-02975492 \\ https://univ-lyon1.hal.science/hal-02975492}

Submitted on 22 Oct 2020

HAL is a multi-disciplinary open access archive for the deposit and dissemination of scientific research documents, whether they are published or not. The documents may come from teaching and research institutions in France or abroad, or from public or private research centers.
L'archive ouverte pluridisciplinaire HAL, est destinée au dépôt et à la diffusion de documents scientifiques de niveau recherche, publiés ou non, émanant des établissements d'enseignement et de recherche français ou étrangers, des laboratoires publics ou privés. 


\title{
Solvent-free synthesis and properties of functionalized hydrazines and bishydrazines as energetic ingredients for propulsion applications
}

\author{
J. Eymann, ${ }^{[a]}$ A. Dhenain, ${ }^{[a]}$ L. Joucla, ${ }^{*[a]}$ G. Jacob,${ }^{[a]}$ E. Lacôte,${ }^{[a]}$ and C. Darwich ${ }^{*[a]}$
}

[a] John Eymann, Dr. Anne Dhenain, Dr. Lionel Joucla, Dr. Guy Jacob, Dr. Emmanuel Lacôte, Dr. Chaza Darwich Laboratoire Hydrazines et Composés Energétiques Polyazotés UCBL/CNRS/CNES/ArianeGroup Université Claude Bernard Lyon 1

2, rue Victor Grignard 69622 Villeurbanne cedex (France)

E-mail: chaza.darwich@univ-lyon1.fr; lionel.joucla@univ-lyon1.fr

Supporting information for this article is given via a link at the end of the document.

\begin{abstract}
Functionalized hydrazines and bishydrazines are interesting straightforward precursors for accessing higher nitrogenated compounds. They offer structural diversity and promising energetic properties as well, namely for propulsion applications. A novel and scalable synthesis has been developed for a new family of bishydrazines, starting from monomethylhydrazine $(\mathrm{MMH})$. This solvent-free route represents a suitable alternative to the one described in the literature. It was extended to design a new family of unsymmetrical hydrazines bearing various functional groups. A selected series of promising compounds, densified with nitrogenated groups (amino, hydrazino or azido functions), was identified as a class of plausible candidates for liquid propulsion. Indeed, the energetic interest of such hydrazines was demonstrated by computing their heats of formation and specific impulse values in bipropellant systems. This led to theoretical energetic performances comparable to that of the $\mathrm{MMH} / \mathrm{N}_{2} \mathrm{O}_{4}$ system already in use today.
\end{abstract}

\section{Introduction}

Rocket propellants performances are characterized by their specific impulse $\left(I_{\mathrm{sp}}\right)$. It is a function of the exit velocity of the exhaust gases, which is proportional to the combustion temperature and inversely proportional to the molecular weight of gaseous products. Besides, nitrogen-nitrogen bond energy increases significantly from a single over a double to a triple bond (respectively 159, 418 and $942 \mathrm{~kJ} \mathrm{~mol}^{-1}$ ). This implies that increasing the number of simple nitrogen-nitrogen bonds in a molecule results in higher, more positive heats of formation, which in turn translates to a greater combustion temperature. ${ }^{[1]}$ In this regard, new hydrazine derivatives should be useful energetic ingredients for higher performance space propellants. This is supported by their overall high positive heats of formation as well as their decomposition into nitrogen gas $(28 \mathrm{~g} / \mathrm{mol})$.

Functionalized hydrazines possess several advantages over low-molecular weight hydrazines already in use in the space industry. They tend to exhibit higher boiling points, higher thermal stabilities, and lower vapor pressures. The latter feature considerably decreases the risks of inhalation and/or explosion especially during the launchers loading step.

Herein we consider a family of functionalized hydrazines and bishydrazines for applications in the field of energetic materials, in particular for space propulsion. ${ }^{[2,3]}$
Bishydrazines have not been thoroughly studied in the literature, especially as potential energetic ingredients. Indeed, only a single bishydrazine synthesis was described, ${ }^{[4]}$ through the nitrosation/reduction of 1,2-dimethylethylenediamine (DMEDA). This synthesis involves highly toxic and carcinogenic nitrosamine derivatives and implies reduction conditions ( $\mathrm{LAH}$, Hydrogen high pressure, etc.) unsuitable for an industrial production.

We therefore propose a new, versatile and scalable route, - i.e. suitable for an industrial production - to access these new compounds. The synthetic strategy uses monomethylhydrazine $(\mathrm{MMH})$ as the starting feedstock and the corresponding chloroalkyl substrates as functionalization reagents (Scheme 1).

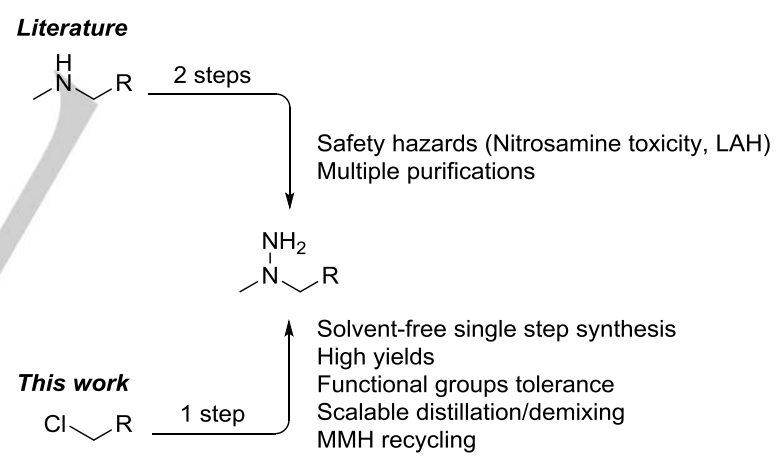

Scheme 1. General synthetic pathway for accessing functionalized hydrazines and bishydrazines.

We also report the results of our investigation into the energetic properties of these nitrogenated hydrazines. We selected the most relevant compounds for propulsion applications ( $\mathrm{N} / \mathrm{C}$ ratio $\geq 1$ ) to perform impact sensitivity tests and DSC measurements. We have undertaken a theoretical approach to compute heats of formation (in the gas phase) using different chemical quantum methods, in association with isodesmic reactions. Calculated values were then injected into a thermodynamics code to perform specific impulse calculations on bipropellant systems involving these candidates as fuels, in association with $\mathrm{N}_{2} \mathrm{O}_{4}$ as the oxidizer. 


\section{Results and Discussion}

Following this synthetic pathway, the reaction between dihalide derivatives and $\mathrm{MMH}$ was considered (Scheme 2).

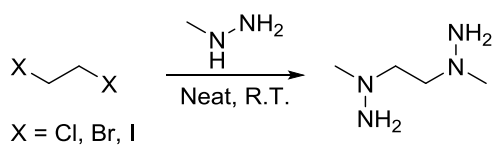

Scheme 2. Synthetic pathway to access the described bishydrazine

\section{Preliminary synthesis essays}

Preliminary tests were carried out on 1,2-dibromoethane and revealed its degradation by $\mathrm{MMH}$ resulting in an unworkable reaction crude. The ${ }^{1} \mathrm{H}$ NMR showed numerous peaks indicating side reactions are taking place. Therefore, the reactivity of the dihalide must be reduced in order to control or prevent this phenomenon. Hence, less reactive and cheaper chlorinated substrates were selected. This would also drastically increase the viability of this route on an industrial scale.

\section{Synthetic route to the new bishydrazines}

Unlike many nucleophilic species exhibiting slow kinetics towards chloride substitution, hydrazines possess a strong alpha effect. $^{[5,6]}$ This considerably accelerates the kinetics of nucleophilic substitutions involving hydrazines which renders the above-mentioned synthetic pathway plausible. Since the modulation of the alpha effect by solvents is not well understood ${ }^{[7]}$ this study was conducted without using solvents. The neat reaction of 1,2-dichloroethane (DCE) and $\mathrm{MMH}$ was described by Böhme et al. ${ }^{[8]}$ in order to access new functionalized hydrazines. The formation of a chloromonohydrazinated compound was mentioned when the reaction was carried out using an excess of DCE, though no dihydrazinated compound was described.

Hence, it seemed necessary to study the selectivity of this reaction by varying the $\mathrm{MMH} / \mathrm{DCE}$ ratio. In these experiments, the limiting reactant was added over 6 hours on the excess reagent by means of a syringe-pump and temperature was maintained at $20^{\circ} \mathrm{C}$ for $24 \mathrm{~h}$.

Results showed that the proportion of the monohydrazinated precursor is the highest when MMH was added slowly (over 12 hours) on 10 equivalents of DCE (Table 1 , line 3 ). On the contrary, a 4-equivalent excess of $\mathrm{MMH}$ is sufficient to selectively favor the dihydrazinated precursor (Table 1, line 4). This can be attributed to the anchimeric assistance (neighboring group participation) in the monohydrazinated derivative leading to the aziridinium intermediate, which greatly facilitates the second substitution (Scheme 3 ).

However, in the latter conditions, the reaction mixture thickens rapidly, preventing the magnetic stirring from functioning properly. On the other hand, this reaction is highly exothermic, which could cause a reaction runaway. Hence, a larger excess of $\mathrm{MMH}$ seems preferable to carry out this synthesis, both to fluidize the reaction mixture and to dissipate the heat released during the reaction (Table 1, line 5).

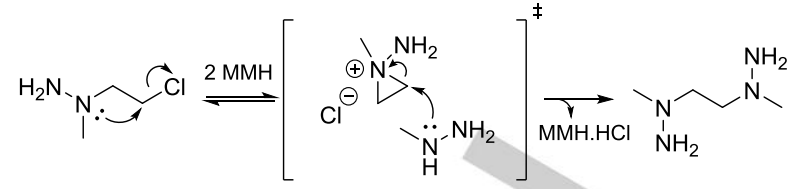

Scheme 3. Mechanism of the dihydrazinated compound formation involving an aziridinium intermediate.

Table 1. Selectivity of the substitution reaction at various MMH/DCE ratios.

\begin{tabular}{llll}
\hline MMH equiv. & DCE equiv. & Monohydrazine[a] & Bishydrazine[a] \\
\hline 1 & 2 & 83 & 17 \\
1 & 4 & 90 & 10 \\
1 & 10 & 94 & 6 \\
4 & 1 & $<5$ & $>95$ \\
8 & 1 & $<5$ & $>95$ \\
\hline
\end{tabular}

[a] compound percentage monitored by NMR.

The monohydrazinated compound was purified by fractional extraction using a $2 \mathrm{~N}$ hydrochloric acid solution. The fractions containing the choro-monohydrazinated precursor were collected, leading to pure compound with a $25 \%$ yield. The dihydrazinated compound was purified by alkalinization with a saturated sodium hydroxide solution, followed by a distillation under reduced pressure $\left(63^{\circ} \mathrm{C}, 1 \mathrm{mbar}\right.$, yield $\left.=55 \%\right)$. This method also allows for the recycling of both the excess of $\mathrm{MMH}$ and the $\mathrm{MMH} . \mathrm{HCl}$ by-product.

As this compound only gave two singlets in ${ }^{1} \mathrm{H}$ NMR, further analyses were conducted to confirm the bishydrazine's structure. Hence, in addition to ${ }^{13} \mathrm{C}$ NMR and MS analyses, the compound was treated with a $2 \mathrm{~N}$ hydrochloric aqueous solution in order to obtain crystals of its dihydrochloride salt and perform a singlecrystal XRD measurement (Figure 1).
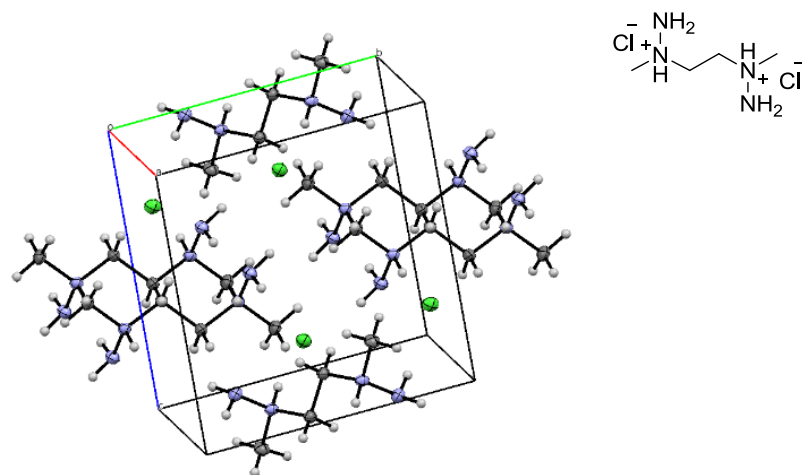

Figure 1. Unit cell of 1,1'-(ethane-1,2-diyl)bis(1-methylhydrazine). $2 \mathrm{HCl}$ salt (ORTEP representation with $50 \%$ ellipsoid).

\section{Scope and limitations}

Structural diversity was ensured by extending this method to various dichloride substrates (Scheme 4). Bishydrazines 1a and 1b are volatile and were therefore purified by distillation. However, distillation attempts on bishydrazines $\mathbf{1 c}$ and $\mathbf{1 d}$ led to thermal degradation. Although less effective, a demixing 
purification step was successfully carried out to extract these two bishydrazines from the reaction crude.

$$
\longrightarrow \text { Cl } \longrightarrow \text { Cl }
$$

Scheme 4. Bishydrazines $1 \mathrm{a}$ to $1 \mathrm{~d}$ obtained from the reaction between $\mathrm{MMH}$ and the corresponding dichloride substrate.

Disubstituted aliphatic alkynes give very weak $\mathrm{C} \equiv \mathrm{C}$ stretching band in IR spectroscopy. A $135^{\circ}$ DEPT NMR analysis was performed to confirm the structure of $\mathbf{1 d}$. The disappearance of the quaternary carbon signal as well as the phase shift of the methylene group suggest the expected alkyne structure was successfully obtained (see SI, Figure S1).

However, this synthesis displays some limitations arising from a side-reactivity observed for dihalogenated substrates presenting a saturated alkyl chain with $n>2$. Thus, 1,3-dichloropropane and 1,4-dichlorobutane led to an intramolecular cyclization (Scheme 5, inputs a, b). As for (Z)-1,4-dichlorobut-2-ene, it quantitatively led to an equimolar mixture of the desired bishydrazine and the corresponding cyclized derivative (Scheme 5 , input c). These substrates are prone to intramolecular cyclization, which is the main side-reaction that competes with the second substitution. The intramolecular cyclization is either kinetically much faster than the second substitution (inputs $a, b$ ) or showing a competitive rate when a pre-arranged unsaturated substrate is used (input c). In the case of 2,3-dichlorobutane, the reaction does not occur -even when potassium iodide is addedbecause of the lack of a primary halide, which inhibits the first substitution step and makes beta anchimeric assistance not possible (Scheme 5 , input d). Results on bishydrazines $\mathbf{1 a}$ to $\mathbf{1 d}$ were patented in 2019. ${ }^{[9]}$

a)

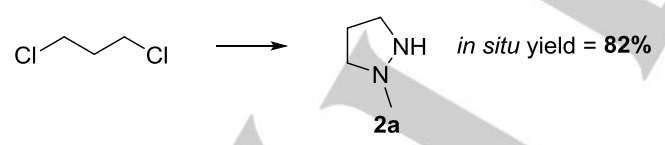

b)<smiles>ClCCCCCl</smiles>

\section{l}

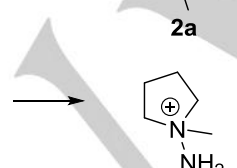

quantitative conversion

c)

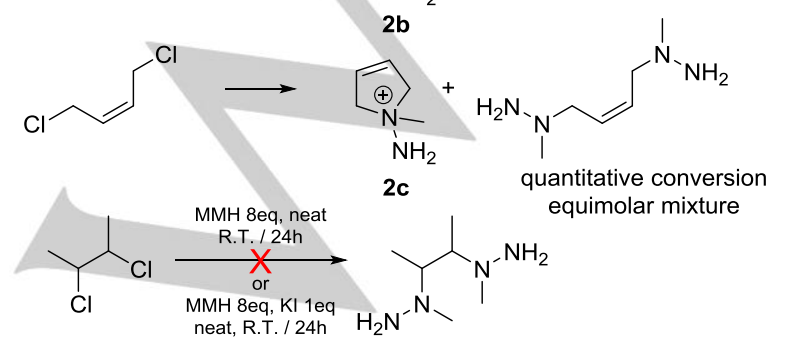

Scheme 5. Limitations of the synthetic method (quantitative conversions were estimated by $1 \mathrm{H}$ NMR).

As a non-separable mixture was obtained from (Z)-dichlorobut2-ene, it was necessary to develop a hydrogenation strategy for compounds 1c and 1d in order to access the desired bishydrazines. Hydrogenation of compound 1c led to 1,1'(butan-1,4-diyl)bis(1-methylhydrazine) 1e with a yield of $82 \%$. Compound $\mathbf{1 f}$ was obtained by partial hydrogenation of $\mathbf{1 d}$ using a Lindlar catalyst (Scheme 6).

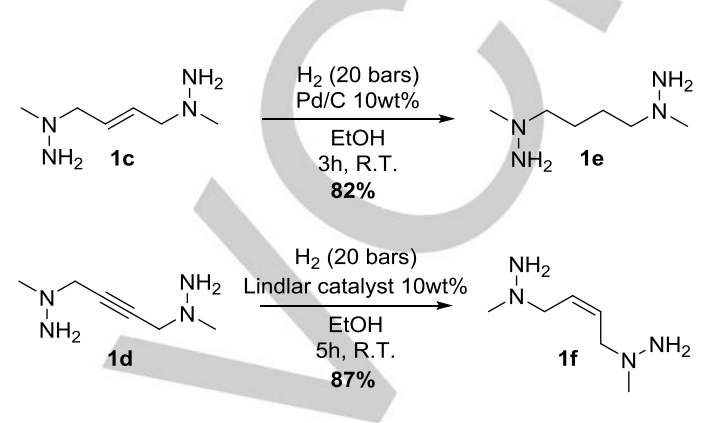

Scheme 6. Hydrogenation of unsaturated bishydrazines 1c and 1d leading to bishydrazines $\mathbf{1 e}$ and $\mathbf{1 f}$.

MS analysis of bishydrazine 1e revealed two fragments resulting from alpha cleavage and beta elimination following the protonation of the substituted nitrogen. The latter was only observed with this bishydrazine due to the availability of beta protons. The resulting fragment led to the formation of two additional adducts (see SI, Scheme S1). This confirmed the structure of this bishydrazine.

\section{Extension of the scope to functionalized hydrazines}

$\beta$-hydroxysubstituted hydrazines were first described by Porath et al. ${ }^{[10]}$ They were synthesized via $\mathrm{N}$-nitrosation of 2(methylamino)-ethanol with butylnitrite, followed by a reduction step with LAH. This synthesis raises the same toxicity and industrial incompatibility issues than that of the dihydrazinated derivatives described by Hogsett et al. ${ }^{[4]}$

Therefore, a new synthesis was developed, ${ }^{[11]}$ based on the laboratory expertise in monochloramine $\left(\mathrm{NH}_{2} \mathrm{Cl}\right) .^{[12]}$ The hydrazinated intermediate was then obtained by direct amination (Raschig process) of 2-(1-methylamino)ethanol with monochloramine (Scheme 7). This synthesis is less hazardous and offers a clearly better yield (crude yield estimated by GC/MS $=92 \%$ ). However, it requires the use of an excess of aminoethanol, which hinders the purification of the hydroxylated hydrazine $3 a^{[11]}$

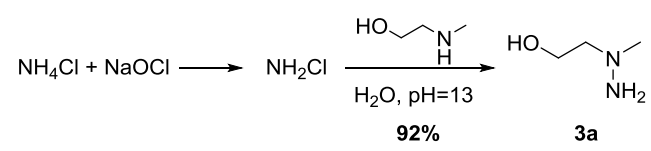

Scheme 7. Synthesis of 2-(1-methylhydrazinyl)-ethan-1-ol (3a) based on monochloramine. ${ }^{[11]}$

Therefore, the aforementioned synthesis method employed for bishydrazines was adapted to chlorinated hydroxyalkyl 
substrates to establish a broad approach for accessing hydroxylsubstituted hydrazines. This led to the corresponding hydroxylated hydrazines $3 a$ to $3 \mathbf{e}$ (Scheme 8 ).

Moreover, aminated hydrazines $\mathbf{3} \mathbf{f}$ and $\mathbf{3 g}$ have been synthesized in the same conditions established for hydroxylated hydrazines with good yields (Scheme 8). An excess of $\mathrm{MMH}$ comparable to that used for the synthesis of bishydrazines (see Table 1, line 5) is necessary due to the neutralization of the commercial hydrochloride salt.

The amine function could generate some incompatibility issues in further reactivity studies involving the hydrazine function. Consequently, the introduction of a suitable protecting group was considered on the amine moieties. The carboxybenzoyl group (Cbz) was selected for its easy removal under mild catalytic hydrogenolysis conditions. These conditions are also likely to be compatible with the hydrazine moiety as well as its higher nitrogenated derivatives. The protection step should obviously take place prior to the introduction of the hydrazine function so as not to cause selectivity problems. The commercially available hydrochloride salts were treated with benzyl chloroformate $(\mathrm{Cbz} \mathrm{Cl})$ in an aqueous alkaline medium to afford excellent yields of the protected intermediates (see SI, Scheme S2). A subsequent nucleophilic substitution with $\mathrm{MMH}$ was performed to access hydrazines $3 \mathbf{h}$ and $\mathbf{3 i}$ with 95 and $98 \%$ yields (Scheme 8 ).

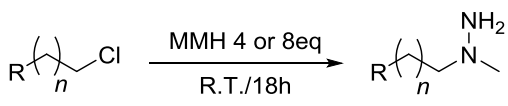

$$
\begin{aligned}
& \mathrm{R}=\mathrm{OH} \quad \mathrm{n}=1 ; \mathbf{8 4 \%} \text { (3a) } \mathrm{R}=\mathrm{NH}_{2} \cdot \mathrm{HCl}^{*} \mathrm{n}=1 \text {; Quant. (3f) } \\
& 2 ; 85 \%(3 \mathrm{~b}) \quad 2 ; 67 \%(3 \mathrm{~g}) \\
& 3 ; 92 \%(3 c) \quad \mathrm{R}=\mathrm{NHCbz} \quad \mathrm{n}=1 ; \mathbf{9 5 \%}(3 \mathrm{~h}) \\
& \begin{array}{l}
4 ; 98 \%(3 d) \\
5 ; 98 \%(3 e)
\end{array}
\end{aligned}
$$

Scheme 8. Synthesis of functionalized hydrazines $\mathbf{3 a}$ to $\mathbf{3 i}$ starting from the corresponding chloroalkyl substrates and $\mathrm{MMH} \mathrm{(*} \mathrm{the} \mathrm{aminated} \mathrm{hydrazines}$ were obtained as neutral compounds $\mathrm{R}=\mathrm{NH}_{2}$ ).

Attempts at activating compound $\mathbf{3 a}$ were performed using tosylchloride in order to densify the structures with nitrogenated functions. Unfortunately, only $\mathrm{NH}$-tosylated by-products were obtained, indicative of the reactant's degradation. Hence, 2-chloroethylhydrazine ${ }^{[8]}$ was considered to access the corresponding $\beta$-azidohydrazine. This was facilitated by the selectivity study performed earlier (see Table 1). The hydrochloride salt of this precursor was neutralized before the aziding step (Scheme 9).

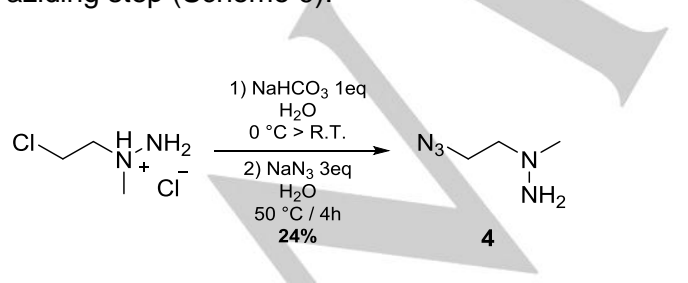

Scheme 9. One-pot aziding step leading to 1-(2-azidoethyl)-1-methylhydrazine (4).

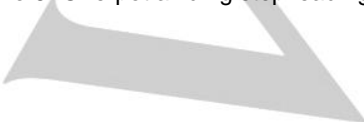

However, the resulting hydrazine proved to be very difficult to extract from its aqueous medium. Additionally, the reaction is very slow at room temperature and leads to various by-products. Several solvents were tried to extract $\mathbf{4}$ from the aqueous medium, and dichloromethane gave best extraction results, its partition coefficient being 5 times higher than that of other organic solvents tested. However, as an excess of sodium azide was needed - otherwise, the reaction is very slow - using dichloromethane as an extraction solvent is not a good option, since the remaining $\mathrm{NaN}_{3}$ can react with $\mathrm{CH}_{2} \mathrm{Cl}_{2}$ to yield extremely explosive diazomethane gas. Thus, ether was used to extract the product, yielding $24 \%$ of 4 (under optimized conditions: $20 \% \mathrm{KOH}$, continuous extraction for $7 \mathrm{~h}$ at ether reflux).

The same approach was not possible with 1,3-dichloropropane, since the reaction of the latter with $\mathrm{MMH}$ does not lead to the corresponding $\gamma$-chlorohydrazine but to 1-methylpyrazolidine (Scheme 5, input a). As a consequence, the corresponding $\gamma$-azidohydrazine could not be obtained this way.

In a similar fashion, the aziding of dichloroalkyl substrates proved not to be selective towards monoazidation and led to unseparable mixtures (distillation of such highly nitrogenated compounds is too risky).

\section{Synthesis of a bifunctionalized hydrazine}

An alternate pathway was designed to access $\gamma$-azided hydrazines using epichlorohydrin as a starting material. Ring opening with sodium azide was described by Gharakhanian et al. ${ }^{[13]}$ Though the regioselectivity of this reaction is contrary to what is usually observed in acidic media, it is not discussed by the authors. The structure of this intermediate was studied by ${ }^{1} \mathrm{H}$ NMR (see SI, Figure S2), which showed that the most deshielded signal appears as a doublet of doublets of triplets $\left({ }^{3} \mathrm{~J}_{\mathrm{HH}}=6.6,5.8,4.4 \mathrm{~Hz}\right)$ and integrates for one proton. The other four diastereotopic protons appear as a doublet of doublets with an important roof effect. Geminal ${ }^{2} \mathrm{~J}_{\mathrm{HH}}$ coupling constants were measured at 13.0 and $11.7 \mathrm{~Hz}$. These data confirmed the structure of 1-azido-3-chloropropan-2-ol. The second step involves the nucleophilic substitution using $\mathrm{MMH}$, which affords hydrazine $\mathbf{5}$ with a $98 \%$ yield (Scheme 10).

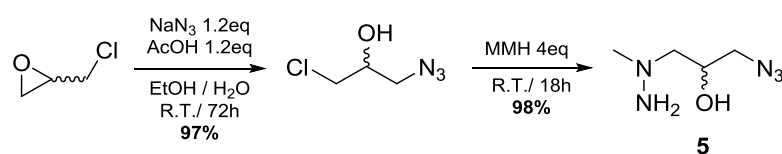

Scheme 10. Synthesis of hydrazine 5 starting from epichlorohydrin.

\section{Energetic properties}

The second part of this study consists in the investigation into the energetic potential of the most relevant synthesized hydrazines. Thereby, a series of energy-densified hydrazines $(\mathrm{N} / \mathrm{C}$ ratio $\geq 1)$ were selected, namely bishydrazine $1 \mathrm{a}, \beta$ aminated hydrazine $\mathbf{3 f}, \beta$-azided hydrazine $\mathbf{4}$, and $\gamma$-azided $\beta$ hydroxylated hydrazine 5 .

\section{Impact sensitivity and thermal stability}

First, their sensitivities towards impact were assessed using standard BAM tests. ${ }^{[14]}$ All four hydrazines showed no senstivity to impact (ISI > 50 J) as a result of a series of ten tests, where each hydrazine was subjected to a $5 \mathrm{Kg}$-weight fall from a $1.019 \mathrm{~m}$ height. 
On the other hand, their thermal stabilities were measured using DSC, which revealed two distinct behaviors. Indeed, both 1 a and $3 f$ have high thermal stabilities up to 246 and $223^{\circ} \mathrm{C}$ respectively This can be attributed to the intermolecular hydrogen bonding network promoted by amino and hydrazino groups. On the other hand, 4 and 5 decompose at 153 and $140^{\circ} \mathrm{C}$ respectively, due to the presence of highly energetic and unstable azido groups. However, these decomposition temperatures are still higher than that of $\mathrm{MMH}$, which is stable up to its boiling point if kept from contact with air (b. p. $\left.=87.5^{\circ} \mathrm{C}\right) .{ }^{[15]}$

\section{Theoretical calculations of energetic performances}

Quantum chemical calculations were performed in order to assess the heats of formation (HOF) of these polynitrogenated hydrazines. They were then injected into a thermodynamic code to estimate the specific impulse values for bipropellant propulsive systems involving these hydrazines as new rocket fuels.

\section{Gas phase Heat of Formation}

Before doing any quantum calculation, one ought to select a suitable model - that is the association of a method and a basis set. Quantum methods differ mostly in how they handle electron correlation, which is an essential parameter for accurately describing any molecular system. Moreover, since the determination of the HOF lies on differences between several enthalpies, the quantum methods used should be sizeconsistent. Previous studies on HOF quantum calculations were reported on related polynitrogenated compounds using various levels of theory. ${ }^{[16,17]}$ The resulting calculated HOF values were compared with experimental ones, to select the most appropriate and accurate level of theory for such compounds. According to these results, compound method CBS-QB3 is the most accurate. However compound methods are expensive and time consuming. Thereby, Density Functional Theory (DFT) methods were also considered. The B3LYP hybrid functional includes the effects of electron correlation and leads to well optimized structures for compounds containing first-row elements. There are also semi-empirical methods that use fitting parameters based on experimental data and which are good enough for structure optimization of small organic compounds. In this work, Gaussian software ${ }^{[18,19]}$ was used to carry out HOF calculations according to three types of quantum methods, with an increasing level of theory. First, geometry optimization and frequency calculations were carried out using the PM6 method. The same calculation procedure was then reiterated with the B3LYP/6-311+G(2d,p) level. Finally, HOF calculations were performed using compound method CBS-QB3 as the highest calculation level. The B3LYP/6-311+G(2d,p) level was chosen on purpose, as it is the one used by the CBS-QB3 method during the geometry optimization step. ${ }^{[20,21]}$

The HOF cannot be calculated directly and thus one must include the compound of interest in a - often hypothetical reaction. Isodesmic bond-separation reactions are largely used for this purpose since they were designed with error cancellation in mind. These hypothetical isodesmic reactions were used to calculate the HOF of the selected hydrazines 1a, 3f, 4 and 5 (see SI for reactions, Scheme S3).

For each hydrazine, the gas phase enthalpy of each species involved in these reactions were computed separately in order to determine $\Delta_{\mathrm{r}} \mathrm{H}^{0}$. They were then used in conjunction with experimental HOF of these species ${ }^{[22-25]}$ to calculate the $\Delta_{\mathrm{f}} \mathrm{H}^{0}$ of the hydrazine (see SI for equations and values, Table S1).

In this work, the two main databases used for the experimental gas phase HOF values are the NIST WebBook of Chemistry ${ }^{[22]}$ and the Handbook of Chemistry \& Physics. ${ }^{[23]}$ Calculated HOF using PM6, B3LYP/6-311+G(2d,p) (geometry optimization done with the same methods, respectively) and CBS-QB3 for the selected series of hydrazines are reported in Table 2.

Table 2. Computed gas phase HOF values for hydrazines 1a, 3f, 4 and 5. Heat of formation $\left(\Delta_{\mathrm{f}} \mathrm{H}^{0}(\mathrm{~g})\right.$, kcal.mol $\left.{ }^{-1}\right)$

\begin{tabular}{llll}
\hline Hydrazine & PM6 $^{[\mathrm{a}]}$ & B3LYP/6-311+G(2d,p $)^{[\mathrm{a}]}$ & CBS-QB3 \\
\hline $\mathbf{1 a}$ & 51.93 & 44.42 & 42.30 \\
$\mathbf{3 f}$ & 23.67 & 24.90 & 23.95 \\
$\mathbf{4}$ & 99.10 & 98.42 & 95.41 \\
$\mathbf{5}$ & 54.26 & 49.01 & 46.87 \\
\hline
\end{tabular}

[a] geometry optimization done with the same theory level.

Calculation results showed that, for the four hydrazines, PM6 and CBS-QB3 give the highest and the lowest value respectively. As mentioned above, CBS-QB3 provides the most accurate HOF compared to experimental values. Thereby, one can conclude that the PM6-computed HOF values are slightly overestimated for hydrazines $\mathbf{1 a}, \mathbf{4}$ and $\mathbf{5}$. However, the effect of this HOF overestimation on the energetic performance of the four hydrazines was further studied. Therefore, the specific impulses $\left(I_{\mathrm{sp}}\right)$ were calculated for propulsive systems involving each of the selected hydrazines using all the available HOF data.

\section{Specific Impulse}

$I_{\text {sp }}$ values were computed with OPHELIE, which is a thermodynamic code used at ArianeGroup. It is a variant of the CEC71 program, ${ }^{[26]}$ which is one of the Chemical Equilibrium Calculations software programs used by NASA to calculate theoretical rocket performances. These calculations involve a number of assumptions. Among them, one can list complete, adiabatic combustion and ideal-gas law. Theoretical performance can vary depending on which assumptions were made for the same propellant and operating conditions. In this work, Isp was calculated for a finite-area combustion (FAC) model, where the combustion chamber is assumed to have a constant cross-sectional area. Chamber pressure and area ratio $\left(\varepsilon=A_{e} / A_{t}\right)$ were set at $7 \mathrm{MPa}$ and 40 respectively. In these conditions, the calculated HOF values were used for the computation of the $\mathrm{I}_{\mathrm{sp}}$ in bipropellant systems with $\mathrm{N}_{2} \mathrm{O}_{4}$ as the oxidizer. For each hydrazine, several compositions were tested with varying Oxidizer/Fuel $(\mathrm{O} / \mathrm{F})$ ratios to maximize $I_{\mathrm{sp}}\left(\mathrm{I}_{\mathrm{sp} \max }\right)$. Results are depicted in Table 3.

Table 3. $I_{\mathrm{sp} \text { max }}$ computed with OPHELIE code for hydrazines 1a, 3f, 4 and 5 $\mathrm{I}_{\mathrm{sp}}$ value (s)

\begin{tabular}{lllll}
\hline Hydrazine Formula & $\begin{array}{l}\text { O/F } \\
\text { ratio }\end{array} \quad$ PM6 $^{[a]} \quad$ B3LYP & CBS-QB3 $^{[a]}$ \\
\hline
\end{tabular}




\begin{tabular}{llllll}
\hline 1a & $\mathrm{C}_{4} \mathrm{H}_{14} \mathrm{~N}_{4}$ & $72 / 28$ & 340.9 & 339.6 & 339.2 \\
$\mathbf{3 f}$ & $\mathrm{C}_{3} \mathrm{H}_{11} \mathrm{~N}_{3}$ & $74 / 26$ & 338.2 & 338.4 & 338.3 \\
$\mathbf{4}$ & $\mathrm{C}_{3} \mathrm{H}_{9} \mathrm{~N}_{5}$ & $64 / 36$ & 341.5 & 341.3 & 340.6 \\
$\mathbf{5}$ & $\mathrm{C}_{4} \mathrm{H}_{11} \mathrm{~N}_{5} \mathrm{O}$ & $64 / 36$ & 334.3 & 333.3 & 332.9 \\
\hline
\end{tabular}

[a] $I_{s p}$ values based on HOF values that were calculated with this level of theory.

One can observe that PM6-computed HOF led to $I_{s p}$ values that are close to those obtained from B3LYP and CBS-QB3computed HOF. The latter methods provide an accurate prediction of specific impulses as the corresponding HOF discrepancies were not transferred to the $I_{s p}$ values (less than 1 point). In all cases, these discrepancies are of low consequence for energetic performance assessments and this method can be used to get a quick order of magnitude for HOF (and thus $I_{\mathrm{sp}}$ ) values, while B3LYP and CBS-QB3 give more reliable results for this study.

Moreover, the calculated specific impulses indicate that the energetic performance of $\mathbf{1 a}$ and $\mathbf{4}$ is comparable to the one of the $\mathrm{MMH} / \mathrm{N}_{2} \mathrm{O}_{4}$ system already in use $\left(\mathrm{I}_{\mathrm{sp} \max }=341.3 \mathrm{~s}\right.$ based on experimental HOF $\left.(\mathrm{MMH})=12.68 \mathrm{kcal} \cdot \mathrm{mol}^{-1}\right) \cdot{ }^{[27]}$ However, the 4-based system ( $\mathrm{N} / \mathrm{C}$ ratio $>1$ ) requires a lower oxidizer amount compared to $1 \mathrm{a}(\mathrm{N} / \mathrm{C}$ ratio $=1)$ or $\mathrm{MMH}$-based $(\mathrm{O} / \mathrm{F}$ ratio $=$ 70/30) ones. On the other hand, the introduction of an $\mathrm{OH}$ group in the molecule drops its performance by 8 points ( 4 and $\mathbf{5}$ ). The same trend can be observed to a lesser extent when comparing the $\mathrm{N} / \mathrm{C}$ ratios of $4(\mathrm{~N} / \mathrm{C}$ ratio $>1)$ and $3 f(N / C$ ratio $=1)$, for which the maximum $\mathrm{I}_{\mathrm{sp}}$ value is around 3 points lower.

\section{Conclusion}

A novel and versatile synthesis for a family of functionalized hydrazines and bishydrazines is reported. It is based on the alkylation of $\mathrm{MMH}$ by chloroalkyl substrates. This synthesis is versatile and led to four new bishydrazines and eleven functionalized hydrazines. Its main limitations were observed in the case of substrates prone to intramolecular cyclization or presenting secondary halides. The properties of the four most energetic hydrazine derivatives revealed low sensitivities to impact and good thermal stabilities. Their HOF values were computed using three different levels of theory (PM6, B3LYP and CBS-QB3 chemical quantum methods) and were then used for assessing the energetic performances of the selected hydrazines in bipropellant systems with $\mathrm{N}_{2} \mathrm{O}_{4}$ as the oxidizer. Three of the studied hydrazines exhibit $I_{\text {sp } \max }$ values similar to that of the $\mathrm{MMH} / \mathrm{N}_{2} \mathrm{O}_{4}$ propellant system. These results establish this class of hydrazine derivatives as key ingredients for new rocket fuels, offering structural diversity and promising energetic prospects simultaneously.

\section{Experimental Section}

General procedure for the synthesis of bishydrazines $1 \mathrm{a}$ to $1 \mathrm{~d}$

$\mathrm{MMH}$ (8eq) was introduced into a double-jacketed vessel and the temperature was set at $20^{\circ} \mathrm{C}$ by means of a cryothermostat. An Argon atmosphere was set up and the dichloride substrate (1eq) was added dropwise over $6 \mathrm{~h}$ by means of a syringe-pump. The reaction mixture was stirred for $18 \mathrm{~h}$ at $20^{\circ} \mathrm{C}$, after which the reaction crude was subjected to either of the following work-up methods:

A) Distillation: The reaction mixture was alkalinized with a freshly prepared saturated aqueous solution of $\mathrm{NaOH}$ and the volatile species were evaporated under reduced pressure. A filtration step of salts formed, followed by vacuum distillation led to a pure compound.

B) Demixing: The reaction mixture was alkalinized with a large excess of a saturated aqueous solution of $\mathrm{NaOH}$, until total demixing of the compound. The organic phase was separated, filtered off to get rid of residual salts and the volatile species were evaporated under reduced pressure, leading to a pure compound.

\section{1,1'-(Ethane-1,2-diyl)bis(1-methylhydrazine) (1a)}

Compound prepared from DCE $(15.0 \mathrm{~mL}, 189.5 \mathrm{mmol})$ and purified according to method $A\left(1 \mathrm{mbar}, 63^{\circ} \mathrm{C}\right)$ leading to $\mathrm{NH}_{2} \quad 12.39 \mathrm{~g}(55 \%)$ of colourless liquid at R. T. $\left(20^{\circ} \mathrm{C}\right) .{ }^{1} \mathrm{H}$ NMR $\mathrm{C}_{4} \mathrm{H}_{14} \mathrm{~N}_{4} \quad\left(\mathrm{D}_{2} \mathrm{O}, 25^{\circ} \mathrm{C}, 300 \mathrm{MHz}\right): \delta(\mathrm{ppm})=2.44(\mathrm{~s}, 6 \mathrm{H}, \mathrm{NMe}), 2.70(\mathrm{~s}$, 118.18 g.mol $\left.{ }^{-1} \quad 4 \mathrm{H}, \quad \mathrm{NCH}_{2}\right) ;{ }^{13} \mathrm{C}\left\{{ }^{1} \mathrm{H}\right\} \quad \mathrm{NMR}\left(\mathrm{D}_{2} \mathrm{O}, 25{ }^{\circ} \mathrm{C}, 75 \mathrm{MHz}\right): \delta$ $(\mathrm{ppm})=47.3(\mathrm{NMe}), 58.3\left(\mathrm{NCH}_{2}\right) ;{ }^{15} \mathrm{~N} \mathrm{NMR}\left(\mathrm{CD}_{3} \mathrm{NO}_{2}, 25^{\circ} \mathrm{C}\right.$, $50 \mathrm{MHz}): \delta(\mathrm{ppm})=66.0\left(\mathrm{NH}_{2} \mathrm{MMe}\right), 93.4\left(\mathrm{NH}_{2} \mathrm{NMe}\right) ; \mathrm{HRMS}\left(\mathrm{ESI}^{+}\right)$: $[\mathrm{M}+\mathrm{H}]^{+} \mathrm{m} / \mathrm{z}=119.1291$ (calcd.), 119.1287 (found); IR (Golden Gate, $v$ $\left.\left(\mathrm{cm}^{-1}\right)\right)=3301(\mathrm{w}), 3138(\mathrm{w}), 2943(\mathrm{~m}), 2831(\mathrm{~m}), 2770(\mathrm{~m}), 1602(\mathrm{~m})$, $1445(\mathrm{~m}), 1324(\mathrm{w}), 1058(\mathrm{~m}), 1025(\mathrm{~m}), 957(\mathrm{~m}), 847(\mathrm{w}), 797(\mathrm{~m}), 768$ $(\mathrm{m}), 584(\mathrm{w}), 550(\mathrm{w}), 531(\mathrm{w}), 500(\mathrm{~m}), 483(\mathrm{~m}), 467(\mathrm{~m})$. DSC (Medium pressure Steel crucible, -50 to $\left.400^{\circ} \mathrm{C}, 5^{\circ} \mathrm{C} / \mathrm{min}\right): \mathrm{T}_{\mathrm{d}}$ (onset) $=246^{\circ} \mathrm{C}$; ISI (BAM, constant energy) $>50 \mathrm{~J}$.

\section{1,1'-(Propane-1,2-diyl)bis(1-methylhydrazine) (1b)}

$\mathrm{NH}_{2} \quad$ Compound prepared from 1,2-dichloropropane (20.0 N $\mathrm{N}^{-}, 204.6 \mathrm{mmol}$ ) and purified according to method $\mathrm{A}$ $\stackrel{\mathrm{N}}{\mathrm{N}_{2}} \quad\left(10^{-2} \mathrm{mbar}, 42{ }^{\circ} \mathrm{C}\right)$, leading to $12.22 \mathrm{~g}(45 \%)$ of $\mathrm{C}_{5} \mathrm{H}_{16} \mathrm{~N}_{4} \quad$ colourless liquid at R. T. $\left(16{ }^{\circ} \mathrm{C}\right)$. ${ }^{1} \mathrm{H}$ NMR $\left(\mathrm{CDCl}_{3}\right.$, $\left.132.21 \mathrm{~g} \cdot \mathrm{mol}^{-1} \quad 25^{\circ} \mathrm{C}, 300 \mathrm{MHz}\right): \delta(\mathrm{ppm})=0.67(\mathrm{~d}, 3 \mathrm{H}, \mathrm{CHMe}, \mathrm{J}=6.6$ 1b $\mathrm{Hz}$ ), 1.95 (dd, 1H, CHHCHMe, J=12.5, $5.2 \mathrm{~Hz}), 2.19$ 2.23 (s, 6H, NMe), 2.41 (dd, 1H, CHHCHMe, J=12.5, $8.0 \mathrm{~Hz}$ ), 2.69 (ddq, $\left.1 \mathrm{H}, \mathrm{CH}_{2} \mathrm{CHMe}, \mathrm{J}=8.0,6.6,5.2 \mathrm{~Hz}\right), 2.80(\mathrm{~s}(\mathrm{~b}), 4 \mathrm{H}$, $\left.\mathrm{NNH}_{2}\right) ;{ }^{13} \mathrm{C}\left\{{ }^{1} \mathrm{H}\right\}$ NMR $\left(\mathrm{CDCl}_{3}, 25{ }^{\circ} \mathrm{C}, 75 \mathrm{MHz}\right): \delta(\mathrm{ppm})=10.9(\mathrm{CHMe})$, $45.7\left(\mathrm{MeNNH}_{2} \mathrm{CHMe}\right), 50.5\left(\mathrm{MeNNH}_{2} \mathrm{CH}_{2} \mathrm{CHMe}\right), 59.3$ (CHMe), 66.5 $\left(\mathrm{NCH}_{2} \mathrm{CHMe}\right) ;{ }^{15} \mathrm{~N}$ NMR $\left(\mathrm{CD}_{3} \mathrm{NO}_{2}, 25{ }^{\circ} \mathrm{C}, 50 \mathrm{MHz}\right): \delta(\mathrm{ppm})=66.1$ $\left(\mathrm{NH}_{2} \mathrm{~N}(\mathrm{Me}) \mathrm{CHMe}\right), 68.3\left(\mathrm{NH}_{2} \mathrm{~N}(\mathrm{Me}) \mathrm{CH}_{2}\right), 83.6\left(\mathrm{NH}_{2} \mathrm{~N}(\mathrm{Me}) \mathrm{CHMe}\right), 94.0$ $\left(\mathrm{NH}_{2} \mathrm{~N}(\mathrm{Me}) \mathrm{CH}_{2}\right)$; HMRS $\left(\mathrm{ESI}^{+}\right):[\mathrm{M}+\mathrm{H}]^{+} \mathrm{m} / \mathrm{z}=133.1448$ (calcd.), 133.1441 (found); IR (Golden Gate, $\left.v\left(\mathrm{~cm}^{-1}\right)\right)=3301(\mathrm{w}), 3149(\mathrm{w}), 2967(\mathrm{w}), 2942$ (w), $2834(w), 2785(w), 1593(m), 1571(m), 1445(m), 1419(w), 1377$ (w), $1308(\mathrm{w}), 1262(\mathrm{w}), 1106(\mathrm{~m}), 1091(\mathrm{~m}), 1069(\mathrm{~m}), 1040(\mathrm{~m}), 974$ $(\mathrm{m}), 956(\mathrm{~m}), 930(\mathrm{~m}), 912(\mathrm{~m}), 890(\mathrm{~m}), 824(\mathrm{~m}), 802(\mathrm{~m}), 774(\mathrm{~m}), 746$ $(\mathrm{m}), 673(\mathrm{~m}), 582(\mathrm{~m}), 572(\mathrm{~m}), 558(\mathrm{~m}), 546(\mathrm{~m}), 538(\mathrm{~m}), 520(\mathrm{~m}), 513$ $(\mathrm{m}), 500(\mathrm{~m}), 491(\mathrm{~m}), 476(\mathrm{~m}), 465(\mathrm{~m})$.

\section{1,1'-((E)-But-2-ene-1,4-diyl)bis(1-methylhydrazine) (1c)}

$\mathrm{NH}_{2}$ Compound prepared from (E)-1,4-dichlorobut-2-ene (15.0 $\mathrm{mL}, 141.6 \mathrm{mmol}$ ) and purified according to $(15.0 \mathrm{~mL}, 141.6 \mathrm{mmol})$ and purified according to
method $\mathrm{B}$, leading to $14.99 \mathrm{~g}(73 \%)$ of amber liquid at $\mathrm{C}_{6} \mathrm{H}_{16} \mathrm{~N}_{4}$ $144.22 \mathrm{~g} \cdot \mathrm{mol}^{-1}$

$1 \mathrm{c}$ R. T. $\left(22^{\circ} \mathrm{C}\right)$. ${ }^{1} \mathrm{H}$ NMR $\left(\mathrm{CDCl}_{3}, 25^{\circ} \mathrm{C}, 300 \mathrm{MHz}\right):$ $(\mathrm{ppm})=2.38\left(\mathrm{~s}, 6 \mathrm{H}, \mathrm{MeNNH}_{2}\right), 2.91\left(\mathrm{~s}(\mathrm{~b}), 4 \mathrm{H}, \mathrm{NNH}_{2}\right)$ 3.03 (dd, 4H, NCH $\left.\mathrm{H}_{2} \mathrm{CH}, J=3.6,1.7 \mathrm{~Hz}\right), 5.64(\mathrm{~m}, 2 \mathrm{H}$, $\left.\mathrm{NCH}_{2} \mathrm{CH}\right) ;{ }^{13} \mathrm{C}\left\{{ }^{1} \mathrm{H}\right\} \quad \mathrm{NMR}\left(\mathrm{CDCl}_{3}, 25{ }^{\circ} \mathrm{C}, 75 \mathrm{MHz}\right): \delta(\mathrm{ppm})=48.8$ $\left(\mathrm{MeNNH}_{2}\right), 65.1\left(\mathrm{NCH}_{2} \mathrm{CH}\right), 130.6\left(\mathrm{NCH}_{2} \mathrm{CH}\right) ;{ }^{15} \mathrm{~N} \mathrm{NMR}\left(\mathrm{CD}_{3} \mathrm{NO}_{2}, 25{ }^{\circ} \mathrm{C}\right.$, $50 \mathrm{MHz}): \delta(\mathrm{ppm})=67.8\left(\mathrm{NH}_{2} \mathrm{~N}(\mathrm{Me}) \mathrm{CH}_{2}\right), 92.6\left(\mathrm{NH}_{2} \mathrm{~N}(\mathrm{Me}) \mathrm{CH}_{2}\right) ; \mathrm{HRMS}$ $\left(\mathrm{ESI}^{+}\right):[\mathrm{M}+\mathrm{H}]^{+} \mathrm{m} / \mathrm{z}=145.1448$ (calcd.), 145.1441 (found); IR (Golden Gate, $\left.v\left(\mathrm{~cm}^{-1}\right)\right)=3302(\mathrm{~m}), 2948(\mathrm{~m}), 2834(\mathrm{~m}), 2785(\mathrm{~m}), 1607(\mathrm{~m})$, 
$1448(\mathrm{~m}), 1414(\mathrm{w}), 1368(\mathrm{w}), 1233(\mathrm{w}), 1026(\mathrm{~m}), 976(\mathrm{~m}), 826(\mathrm{~m}), 763$ $(\mathrm{m}), 661(\mathrm{~m}), 640(\mathrm{~m}), 617(\mathrm{~m}), 591(\mathrm{~m}), 551(\mathrm{~m}), 544(\mathrm{~m})$.

\section{1,1'-(But-2-yne-1,4-dyil)bis(1-methylhydrazine) (1d)}

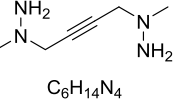

$$
\begin{aligned}
& \begin{array}{c}
\mathrm{C}_{6} \mathrm{H}_{14} \mathrm{~N}_{4} \\
142.21 \mathrm{~g} \cdot \mathrm{mol}^{-1}
\end{array} \\
& \text { 1d }
\end{aligned}
$$

Compound prepared from 1,4-dichlorobut-2-yne (11.6 $\mathrm{mL}, 118.7 \mathrm{mmol}$ ) and purified according to method $\mathrm{B}$, leading to $13.48 \mathrm{~g}(80 \%)$ of yellow liquid at $\mathrm{R}$. $\mathrm{T}$. $\left(23{ }^{\circ} \mathrm{C}\right) . \quad{ }^{1} \mathrm{H} \quad \mathrm{NMR} \quad\left(\mathrm{CDCl}_{3}, 25^{\circ} \mathrm{C}, 300 \mathrm{MHz}\right)$ $\delta(\mathrm{ppm})=2.50(\mathrm{~s}, 6 \mathrm{H}, \mathrm{NMe}), 3.20\left(\mathrm{~s}(\mathrm{~b}), 4 \mathrm{H}, \mathrm{NNH} \mathrm{H}_{2}\right.$, 3.52 (s, 4H, NCH2 $) ;{ }^{13} \mathrm{C} \quad\left\{{ }^{1} \mathrm{H}\right\} \quad \mathrm{NMR}\left(\mathrm{CDCl}_{3}, 25{ }^{\circ} \mathrm{C} ; 75 \mathrm{MHz}\right)$ : $\delta(\mathrm{ppm})=47.5(\mathrm{NMe}), 51.8\left(\mathrm{NCH}_{2}\right), 79.9\left(\mathrm{CH}_{2} \mathrm{C}\right) ;{ }^{15} \mathrm{~N} \mathrm{NMR}\left(\mathrm{CD}_{3} \mathrm{NO}_{2}\right.$, $\left.25{ }^{\circ} \mathrm{C}, 50 \mathrm{MHz}\right): \delta(\mathrm{ppm})=61.1\left(\mathrm{NH}_{2} \mathrm{~N}(\mathrm{Me}) \mathrm{CH}_{2}\right), 89.1\left(\mathrm{NH}_{2} \mathrm{~N}(\mathrm{Me}) \mathrm{CH}_{2}\right)$; HRMS $\left(\mathrm{ESI}^{+}\right):[\mathrm{M}+\mathrm{H}]^{+} \mathrm{m} / \mathrm{z}=143.1291$ (calcd.), 143.1292 (found); IR (Golden Gate, $\left.v\left(\mathrm{~cm}^{-1}\right)\right)=3296(\mathrm{w}), 2946(\mathrm{w}), 2781(\mathrm{w}), 1603(\mathrm{~m}), 1445$ $(\mathrm{m}), 1324(\mathrm{~m}), 1098(\mathrm{~m}), 1028(\mathrm{~m}), 949(\mathrm{~m}), 800(\mathrm{~m}), 643(\mathrm{~m})$

\section{Synthesis of bishydrazines $1 \mathrm{e}$ and $1 \mathrm{f}$ by catalytic hydrogenation}

\section{1,1'-(Butane-1,4-diyl)bis(1-methylhydrazine) (1e)}

$$
\underset{\substack{146.24 \\ \mathbf{l e}}}{\mathrm{C}_{6} \mathrm{Hol}_{18}^{-1}}
$$

$\mathrm{NH}_{2} \quad$ Hydrazine 1c $(2.42 \mathrm{~g}, 16.76 \mathrm{mmol})$ was introduced into a $300 \mathrm{~mL}$ thermostated hydrogenation reactor and diluted in $100 \mathrm{~mL}$ of absolute ethanol. $\mathrm{Pd} / \mathrm{C}$ catalyst was then added (247.0 $\mathrm{mg}, 1 \mathrm{wt} \% \mathrm{Pd})$ and a 20 bars hydrogen atmosphere was set up in the reactor. The reaction was allowed to continue for $5 \mathrm{~h}$ at $20^{\circ} \mathrm{C}$, after which the reaction mixture was filtered off on celite and the solvent evaporated under vacuum to lead to pure compound as a yellow liquid (2.01g, $82 \%)$.

${ }^{1} \mathrm{H}$ NMR $\left(\mathrm{CDCl}_{3}, 25^{\circ} \mathrm{C}, 300 \mathrm{MHz}\right): \delta$ (ppm)=1.54 (quint., $4 \mathrm{H}, \mathrm{MeNCH}_{2} \mathrm{CH}_{2}$ $J=3.5 \mathrm{~Hz}$ ), $2.42\left(\mathrm{~m}, 4 \mathrm{H}, \mathrm{MeNCH}_{2} \mathrm{CH}_{2}\right), 2.43$ (s, 6H, MeN), 2.85 (s(b), 4H, $\left.\mathrm{NNH}_{2}\right) ;{ }^{13} \mathrm{C}\left\{{ }^{1} \mathrm{H}\right\} \quad \mathrm{NMR}\left(\mathrm{CDCl}_{3}, 25^{\circ} \mathrm{C}, 75 \mathrm{MHz}\right): \delta(\mathrm{ppm})=25.3$ $\left(\mathrm{MeNCH}_{2} \mathrm{CH}_{2}\right), 49.8(\mathrm{MeN}), 63.4\left(\mathrm{MeNCH}_{2} \mathrm{CH}_{2}\right) ;{ }^{15} \mathrm{~N} \mathrm{NMR}\left(\mathrm{CD}_{3} \mathrm{NO}_{2}\right.$, $\left.25^{\circ} \mathrm{C}, 50 \mathrm{MHz}\right): \delta(\mathrm{ppm})=68.3\left(\mathrm{NH}_{2} \mathrm{~N}(\mathrm{Me}) \mathrm{CH}_{2}\right), 92.7\left(\mathrm{NH}_{2} \mathrm{~N}(\mathrm{Me}) \mathrm{CH}_{2}\right)$; HMRS (ESI ${ }^{+}$: $[\mathrm{M}+\mathrm{H}]^{+} \mathrm{m} / \mathrm{z}=147.1604$ (calcd.), 147.1605 (found); $[\mathrm{M}+\mathrm{Na}]^{+}$ $\mathrm{m} / \mathrm{z}=169.1424$ (calcd.), 169.1426 (found); IR (Golden Gate, $v\left(\mathrm{~cm}^{-1}\right)$ ): $3295(w), 2942(m), 2783(m), 1599(w), 1446(m), 1377(w), 1051(m)$, $940(\mathrm{~m}), 821(\mathrm{~m})$.

\section{1,1'-((Z)-But-2-ene-1,4-diyl)bis(1-methylhydrazine) (1f)}

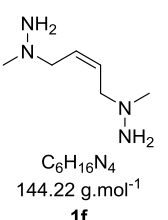

Hydrazine 1d (2.50 g, $17.56 \mathrm{mmol})$ was introduced into a $300 \mathrm{~mL}$ thermostated hydrogenation reactor and diluted in $100 \mathrm{~mL}$ of absolute ethanol. The mixture was then loaded with Lindlar catalyst $(247.0 \mathrm{mg}, 10 \mathrm{wt} \%)$ and a 20 bars hydrogen atmosphere was set up in the vessel. The reaction continued for $3 \mathrm{~h}$ at $20^{\circ} \mathrm{C}$, after which the reaction mixture was filtered off on celite and the solvent was evaporated under reduced pressure, yielding the pure compound as an orange liquid $(2.22 \mathrm{~g}, 88 \%)$

${ }^{1} \mathrm{H} \mathrm{NMR}\left(\mathrm{CDCl}_{3}, 25^{\circ} \mathrm{C}, 300 \mathrm{MHz}\right): \delta(\mathrm{ppm})=2.47(\mathrm{~s}, 6 \mathrm{H}, \mathrm{NMe}), 3.17$ (dd, $\left.4 \mathrm{H}, \mathrm{NCH}_{2}, \mathrm{~J}=1.1,4.1 \mathrm{~Hz}\right), 5.73\left(\mathrm{~m}, 2 \mathrm{H}, \mathrm{NCH}_{2} \mathrm{CH}\right) ;{ }^{13} \mathrm{C}\left\{{ }^{1} \mathrm{H}\right\} \mathrm{NMR}\left(\mathrm{CDCl}_{3}\right.$, $\left.25^{\circ} \mathrm{C}, 75 \mathrm{MHz}\right): \delta(\mathrm{ppm})=49.3(\mathrm{NMe}), 60.1\left(\mathrm{NCH}_{2}\right), 129.5\left(\mathrm{NCH}_{2} \mathrm{CH}\right)$; ${ }^{15} \mathrm{~N}$ NMR $\left(\mathrm{CD}_{3} \mathrm{NO}_{2}, 25^{\circ} \mathrm{C}, 50 \mathrm{MHz}\right): \delta(\mathrm{ppm})=68.5\left(\mathrm{NH}_{2} \mathrm{~N}(\mathrm{Me}) \mathrm{CH}_{2}\right), 93.3$ $\left(\mathrm{NH}_{2} \mathrm{~N}(\mathrm{Me}) \mathrm{CH}_{2}\right) ; \mathrm{HRMS}\left(\mathrm{ESI}^{+}\right)[\mathrm{M}+\mathrm{H}]^{+}: \mathrm{m} / \mathrm{z}=145.1448$ (calcd.), 145.1448 (found), $[\mathrm{M}+\mathrm{Na}]^{+} \mathrm{m} / \mathrm{z}=167.1267$ (calcd.), 167.1267 (found); IR (Golden Gate, $\left.v\left(\mathrm{~cm}^{-1}\right)\right)=3301(w), 3138(w), 2946(w), 2830(w), 2774(w), 1601(w)$, 1446(m), 1320(w), 1256(w), 1107(w), 1030(m), 939(m), 828(m), 696(w), 567(w), 536(w), 520(w), 513(w), 502(w), 492(w), 482(w).

\section{General procedure for the synthesis of hydrazines $3 a$ to $3 e$}

An inert Argon atmosphere was set-up inside a thermostated double-jacketed vessel, then $\mathrm{MMH}(4 \mathrm{eq})$ was introduced at $20^{\circ} \mathrm{C}$. The chlorinated hydroxyalkyl substrate (1eq) was added slowly (over 6h) by means of a syringe-pump and the solution was stirred for an additional $18 \mathrm{~h}$ at $20^{\circ} \mathrm{C}$. The reaction mixture was then alkalinized by adding a freshly prepared aqueous solution of $\mathrm{NaOH}$ (50wt\%, 2.05eq). The reaction crude was then evaporated under reduced pressure to remove residual $\mathrm{MMH}$ and water and then diluted in acetonitrile in order to precipitate salts, which were filtered off. The solvent was then evaporated under reduced pressure, leading to a pure compound.

\section{2-(1-Methylhydrazinyl)ethan-1-ol (3a)}

${ }_{\mathrm{N}} \widehat{\mathrm{OH}}$ Compound prepared from 2-chloroethan-1-ol (16.7 mL, $\mathrm{NH}_{2} \quad 248 \mathrm{mmol}$ ), yielding $18.522 \mathrm{~g}(83 \%)$ as a colorless liquid at $\mathrm{C}_{3} \mathrm{H}_{10} \mathrm{~N}_{2} \mathrm{O} \quad$ R. T. $\left(23^{\circ} \mathrm{C}\right) \cdot \mathrm{d}\left(23.3^{\circ} \mathrm{C}\right)=1.0234 ;{ }^{1} \mathrm{H}$ NMR $\left(\mathrm{CDCl}_{3}, 25^{\circ} \mathrm{C}\right.$, $\left.\begin{array}{c}90.1244 \mathrm{~g}_{3} \cdot \mathrm{mol}^{-1} \\ 3 \mathrm{a}\end{array} 300 \mathrm{MHz}\right): \delta(\mathrm{ppm})=2.47(\mathrm{~s}, 3 \mathrm{H}, \mathrm{NMe}), 2.52(\mathrm{~m}, 2 \mathrm{H}$, $\left.\mathrm{NCH}_{2} \mathrm{CH}_{2} \mathrm{OH}\right), 3.59$ (s(b), $3 \mathrm{H}, \mathrm{MeN}\left(\mathrm{NH}_{2}\right) \mathrm{CH}_{2} \mathrm{CH}_{2} \mathrm{OH}$ ), 3.72 $\left(\mathrm{m}, 2 \mathrm{H}, \mathrm{NCH}_{2} \mathrm{CH}_{2} \mathrm{OH}\right) ;{ }^{13} \mathrm{C}\left\{{ }^{1} \mathrm{H}\right\} \mathrm{NMR}\left(\mathrm{CDCl}_{3}, 25^{\circ} \mathrm{C}, 75 \mathrm{MHz}\right): \delta(\mathrm{ppm})=$ 51.7 (NMe), $61.9\left(\mathrm{CH}_{2} \mathrm{OH}\right), 62.2\left(\mathrm{CH}_{2} \mathrm{~N}\right) ;{ }^{15} \mathrm{~N} \mathrm{NMR}\left(\mathrm{CD}_{3} \mathrm{NO}_{2}, 25^{\circ} \mathrm{C}, 50\right.$ $\mathrm{MHz}): \delta(\mathrm{ppm})=66.4\left(\mathrm{NH}_{2} \mathrm{MMe}\right), 91.8\left(\mathrm{NH}_{2} \mathrm{NMe}\right) . \mathrm{HRMS}\left(\mathrm{ESI}^{+}\right):[\mathrm{M}+\mathrm{H}]^{+}$ $\mathrm{m} / \mathrm{z}=91.0866$ (calcd.), 91.0862 (found); $[\mathrm{M}+\mathrm{Na}]^{+} \mathrm{m} / \mathrm{z}=113.0685$ (calcd.), 113.0686 (found); IR (Golden Gate, $\left.v\left(\mathrm{~cm}^{-1}\right)\right)=3301(\mathrm{~m}(\mathrm{~b})), 2946(\mathrm{~m})$, $2836(\mathrm{~m}), 2789(\mathrm{~m}), 1607(\mathrm{w}), 1448(\mathrm{~m}), 1364(\mathrm{w}), 1272(\mathrm{w}), 1079(\mathrm{~m})$ $1034(\mathrm{~m}), 880(\mathrm{~m}), 833(\mathrm{w}), 770(\mathrm{~m}), 599(\mathrm{w}), 681(\mathrm{w}), 631(\mathrm{w}), 555(\mathrm{~m})$, $538(\mathrm{~m}), 480(\mathrm{~m}), 472(\mathrm{~m})$.

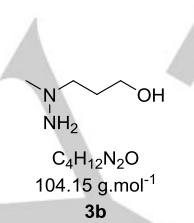

\section{3-(1-Methylhydrazinyl)propan-1-ol (3b)}

Compound prepared from 3-chloropropan-1-ol (44 mL, $526.4 \mathrm{mmol})$, yielding $53.26 \mathrm{~g}(97 \%)$ as a colorless liquid at R. T. $\left(19{ }^{\circ} \mathrm{C}\right) .{ }^{1} \mathrm{H} \mathrm{NMR}\left(\mathrm{CDCl}_{3}, 25^{\circ} \mathrm{C}, 300 \mathrm{MHz}\right)$ $\delta(\mathrm{ppm})=1.74\left(\mathrm{tt}, 2 \mathrm{H}, \mathrm{NCH}_{2} \mathrm{CH}_{2} \mathrm{CH}_{2} \mathrm{OH}, J=5.8,5.4 \mathrm{~Hz}\right.$ ), 2.47 (s, 3H, NMe), 2.61 (t, $2 \mathrm{H}, \mathrm{NCH}_{2} \mathrm{CH}_{2} \mathrm{CH}_{2} \mathrm{OH}, J=5.8$ $\mathrm{Hz}$ ), 3.52 (s(b), 3H, $\mathrm{CH}_{2} \mathrm{OH}, \mathrm{NNH}_{2}$ ), 3.70 (t, $2 \mathrm{H}, \mathrm{NCH}_{2} \mathrm{CH}_{2} \mathrm{CH}_{2} \mathrm{OH}, J=5.4$ $\mathrm{Hz}) ;{ }^{13} \mathrm{C} \quad\left\{{ }^{1} \mathrm{H}\right\} \quad \mathrm{NMR} \quad\left(\mathrm{CDCl}_{3}, 25{ }^{\circ} \mathrm{C}, \quad 75 \quad \mathrm{MHz}\right): \quad \delta(\mathrm{ppm})=29.6$

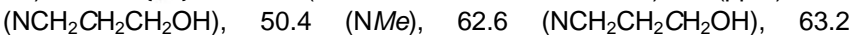
$\left(\mathrm{NCH}_{2} \mathrm{CH}_{2} \mathrm{CH}_{2} \mathrm{OH}\right) ;{ }^{15} \mathrm{~N} \mathrm{NMR}\left(\mathrm{CD}_{3} \mathrm{NO}_{2}, 25{ }^{\circ} \mathrm{C}, 50 \mathrm{MHz}\right): \delta(\mathrm{ppm})=67.9$ $\left(\mathrm{NH}_{2} \mathrm{~N}(\mathrm{Me}) \mathrm{CH}_{2}\right), \quad 91.4 \quad\left(\mathrm{NH}_{2} \mathrm{~N}(\mathrm{Me}) \mathrm{CH}_{2}\right) ; \quad \mathrm{HRMS} \quad\left(\mathrm{ESI}^{+}\right): \quad[\mathrm{M}+\mathrm{H}]^{+}$ $\mathrm{m} / \mathrm{z}=105.1022$ (calcd.), 105.1025 (found), $[\mathrm{M}+\mathrm{Na}]^{+} \mathrm{m} / \mathrm{z}=127.0842$ (calcd.), 127.0845 (found); IR (Golden Gate, $\left.v\left(\mathrm{~cm}^{-1}\right)\right)=3300(\mathrm{~m}(\mathrm{~b})), 2944(\mathrm{~m})$, $2846(\mathrm{~m}), 1609$ (w), 1450 (w), $1377(\mathrm{w}), 1219(\mathrm{w}), 1058(\mathrm{~m}), 969(\mathrm{w}), 930$ (w), $822(\mathrm{w}), 750(\mathrm{~m}), 695(\mathrm{~m}), 676(\mathrm{~m}), 659(\mathrm{~m}), 634(\mathrm{~m}), 624(\mathrm{~m}), 582$ (m), $568(\mathrm{~m}), 481(\mathrm{~m}), 466(\mathrm{~m}), 456(\mathrm{~m})$.

\section{4-(1-Methylhydrazinyl)butan-1-ol (3c)}

OH Compound prepared from 4-chlorobutan-1-ol $(4.2 \mathrm{~mL}$ $\left.\mathrm{NH}_{2} \quad 35.4 \mathrm{mmol}\right)$, yielding $4.59 \mathrm{~g}(92 \%)$ as a yellow liquid at $\mathrm{C}_{5} \mathrm{H}_{14} \mathrm{~N}_{2} \mathrm{O}$ R. T. $\left(21^{\circ} \mathrm{C}\right) .{ }^{1} \mathrm{H}$ NMR $\left(\mathrm{CDCl}_{3}, 25{ }^{\circ} \mathrm{C}, 300 \mathrm{MHz}\right)$ : $118.18{\mathrm{~g} \cdot \mathrm{mol}^{-1}}^{-1} \delta(\mathrm{ppm})=1.67\left(\mathrm{~m}, 4 \mathrm{H}, \mathrm{NCH}_{2} \mathrm{CH}_{2} \mathrm{CH}_{2} \mathrm{CH}_{2} \mathrm{OH}\right), 2.48$ (t, $2 \mathrm{H}, \mathrm{NCH}_{2} \mathrm{CH}_{2} \mathrm{CH}_{2} \mathrm{CH}_{2} \mathrm{OH}, J=5.9 \mathrm{~Hz}$ ), 2.50 (s, $3 \mathrm{H}$, $\mathrm{NMe}$ ), 3.59 (t, $2 \mathrm{H}, \mathrm{NCH}_{2} \mathrm{CH}_{2} \mathrm{CH}_{2} \mathrm{CH}_{2} \mathrm{OH}, J=5.1 \mathrm{~Hz}$ ), $3.85(\mathrm{~s}(\mathrm{~b}), 3 \mathrm{H}$, $\left.\mathrm{CH}_{2} \mathrm{OH}, \mathrm{NNH}_{2}\right) ;{ }^{13} \mathrm{C}\left\{{ }^{1} \mathrm{H}\right\} \mathrm{NMR}\left(\mathrm{CDCl}_{3}, 25^{\circ} \mathrm{C}, 75 \mathrm{MHz}\right): \delta(\mathrm{ppm})=25.7$ $\left(\mathrm{NCH}_{2} \mathrm{CH}_{2} \mathrm{CH}_{2} \mathrm{CH}_{2} \mathrm{OH}\right), 32.0\left(\mathrm{NCH}_{2} \mathrm{CH}_{2} \mathrm{CH}_{2} \mathrm{CH}_{2} \mathrm{OH}\right), 49.8$ (NMe), 62.8$63.0\left(\mathrm{NCH}_{2} \mathrm{CH}_{2} \mathrm{CH}_{2} \mathrm{CH}_{2} \mathrm{OH}\right) ; \mathrm{HRMS}\left(\mathrm{ESI}^{+}\right):[\mathrm{M}+\mathrm{Na}]^{+} \mathrm{m} / \mathrm{z}=119.1179$ (calcd.), 119.1178 (found).

\section{5-(1-Methylhydrazinyl)pentan-1-ol (3d)}

$\mathrm{OH}_{\mathrm{OH}}$ Compound prepared from 5-chloropentan-1-ol (1.06 $\mathrm{CH}_{2} \mathrm{H}_{16} \mathrm{~N}_{2} \mathrm{O} \quad \mathrm{mL}, 8.2 \mathrm{mmol}$ ), yielding $1.06 \mathrm{~g}(98 \%)$ as a colorless 132.21 g.mol ${ }^{-1} \quad$ liquid at R. T. $\left(21^{\circ} \mathrm{C}\right) .{ }^{1} \mathrm{H} \mathrm{NMR}\left(\mathrm{CDCl}_{3}, 25^{\circ} \mathrm{C}, 300\right.$ 3d $\quad \mathrm{MHz}): \quad \delta(\mathrm{ppm})=1.41 \quad(\mathrm{~m}, \quad 2 \mathrm{H}$, $\mathrm{NCH}_{2} \mathrm{CH}_{2} \mathrm{CH}_{2} \mathrm{CH}_{2} \mathrm{CH}_{2} \mathrm{OH}$ ), 1.57 (m, 4H, NCH $\mathrm{CH}_{2} \mathrm{CH}_{2} \mathrm{CH}_{2} \mathrm{CH}_{2} \mathrm{OH}$ ), 2.45 (t, $2 \mathrm{H}, \mathrm{NCH}_{2} \mathrm{CH}_{2} \mathrm{CH}_{2} \mathrm{CH}_{2} \mathrm{CH}_{2} \mathrm{OH}, J=7.2 \mathrm{~Hz}$ ), 2.46 (s, 3H, NMe), 2.90 (s(b), $3 \mathrm{H}, \mathrm{CH}_{2} \mathrm{OH}, \mathrm{NNH}_{2}$ ), 3.63 (t, $2 \mathrm{H}, \mathrm{NCH}_{2} \mathrm{CH}_{2} \mathrm{CH}_{2} \mathrm{CH}_{2} \mathrm{CH}_{2} \mathrm{OH}, J=6.4 \mathrm{~Hz}$ );

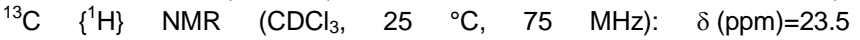
$\left(\mathrm{NCH}_{2} \mathrm{CH}_{2} \mathrm{CH}_{2} \mathrm{CH}_{2} \mathrm{CH}_{2} \mathrm{OH}\right), \quad 27.2 \quad\left(\mathrm{NCH}_{2} \mathrm{CH}_{2} \mathrm{CH}_{2} \mathrm{CH}_{2} \mathrm{CH}_{2} \mathrm{OH}\right), \quad 32.6$ 
$\left(\mathrm{NCH}_{2} \mathrm{CH}_{2} \mathrm{CH}_{2} \mathrm{CH}_{2} \mathrm{CH}_{2} \mathrm{OH}\right)$

49.7

(NMe),

62.7-63.3 $\left(\mathrm{NCH}_{2} \mathrm{CH}_{2} \mathrm{CH}_{2} \mathrm{CH}_{2} \mathrm{CH}_{2} \mathrm{OH}\right) ; \mathrm{HRMS}\left(\mathrm{ESI}^{+}\right)$: $[\mathrm{M}+\mathrm{H}]^{+} \mathrm{m} / \mathrm{z}=133.1335$ (calcd.) 133.1335 (found).

\section{6-(1-Methylhydrazinyl)hexan-1-ol (3e)}

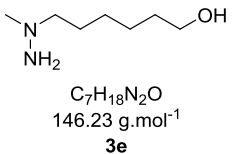

Compound prepared from 6-chlorohexan-1-o (1.02 $\mathrm{mL}, 7.3 \mathrm{mmol})$ yielding $1.05 \mathrm{~g}(98 \%)$ as a colorless liquid at R. T. $\left(21^{\circ} \mathrm{C}\right) .{ }^{1} \mathrm{H}$ NMR $\left(\mathrm{CDCl}_{3}\right.$, $\left.25{ }^{\circ} \mathrm{C}, 300 \mathrm{MHz}\right): \delta(\mathrm{ppm})=1.36(\mathrm{~m}, 4 \mathrm{H}$ $\left.\mathrm{NCH}_{2} \mathrm{CH}_{2} \mathrm{CH}_{2} \mathrm{CH}_{2} \mathrm{CH}_{2} \mathrm{CH}_{2} \mathrm{OH}\right), \quad 1.53 \quad(\mathrm{~m}, \quad 4 \mathrm{H}$ $\mathrm{NCH}_{2} \mathrm{CH}_{2} \mathrm{CH}_{2} \mathrm{CH}_{2} \mathrm{CH}_{2} \mathrm{CH}_{2} \mathrm{OH}$ ), 2.43 (t, $2 \mathrm{H}, \mathrm{NCH}_{2} \mathrm{CH}_{2} \mathrm{CH}_{2} \mathrm{CH}_{2} \mathrm{CH}_{2} \mathrm{CH}_{2} \mathrm{OH}$ $J=7.5 \mathrm{~Hz}$ ), 2.44 (s, 3H, NMe), 2.81 (s(b), 3H, $\mathrm{CH}_{2} \mathrm{OH}, \mathrm{NNH}_{2}$ ), 3.61 (t, $2 \mathrm{H}$, $\left.\mathrm{NCH}_{2} \mathrm{CH}_{2} \mathrm{CH}_{2} \mathrm{CH}_{2} \mathrm{CH}_{2} \mathrm{CH} \mathrm{OH}_{2} \mathrm{~J}=6.5 \mathrm{~Hz}\right) ;{ }^{13} \mathrm{C}\left\{{ }^{1} \mathrm{H}\right\} \mathrm{NMR}\left(\mathrm{CDCl}_{3}, 25^{\circ} \mathrm{C}\right.$, $75 \mathrm{MHz}): \quad \delta(\mathrm{ppm})=25.8 \quad\left(\mathrm{NCH}_{2} \mathrm{CH}_{2} \mathrm{CH}_{2} \mathrm{CH}_{2} \mathrm{CH}_{2} \mathrm{CH}_{2} \mathrm{OH}\right), \quad 27.1$ $\left(\mathrm{NCH}_{2} \mathrm{CH}_{2} \mathrm{CH}_{2} \mathrm{CH}_{2} \mathrm{CH}_{2} \mathrm{CH}_{2} \mathrm{OH}\right), 27.5 \quad\left(\mathrm{NCH}_{2} \mathrm{CH}_{2} \mathrm{CH}_{2} \mathrm{CH}_{2} \mathrm{CH}_{2} \mathrm{CH}_{2} \mathrm{OH}\right)$,

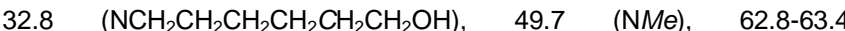
$\left(\mathrm{NCH}_{2} \mathrm{CH}_{2} \mathrm{CH}_{2} \mathrm{CH}_{2} \mathrm{CH}_{2} \mathrm{CH}_{2} \mathrm{OH}\right) ; \operatorname{HRMS}\left(\mathrm{ESI}^{+}\right)$: $[\mathrm{M}+\mathrm{H}]^{+} \mathrm{m} / \mathrm{z}=147.1492$ (calcd.), 147.1486 (found).

\section{General procedure for the synthesis of hydrazines $3 f$ and $3 \mathrm{~g}$}

An inert Argon atmosphere was set-up inside a thermostated double-jacketed vessel, $\mathrm{MMH}$ (8eq) was then introduced into it and the temperature was maintained $20^{\circ} \mathrm{C}$. Chloroalkylamine hydrochloride (1eq) was then added by portions and the reaction mixture was stirred for $18 \mathrm{~h}$ at $20^{\circ} \mathrm{C}$, after which it was alkalinized using an aqueous solution of $\mathrm{NaOH}$ (1.05eq, 50wt\%). The reaction crude was then evaporated under reduced pressure, to get rid of water and residual $\mathrm{MMH}$, and it was diluted in acetonitrile to precipitate salts which were filtered off. Solvent was evaporated under reduced pressure, leading to pure hydrazine.

\section{2-(1-Methylhydrazinyl)ethan-1-amine (3f)}

$\mathrm{N} \sim \mathrm{NH}_{2}$ Compound prepared from 2-chloroethylamine $\mathrm{N}_{2} \quad$ hydrochloride $(10.0 \mathrm{~g}, 86.2 \mathrm{mmol})$ yielding $7.96 \mathrm{~g}$ $\mathrm{C}_{3} \mathrm{H}_{11} \mathrm{~N}_{3}$ (Quant.) as a pale pink liquid at R. T. $\left(22^{\circ} \mathrm{C}\right) \cdot \mathrm{d}\left(21.6^{\circ} \mathrm{C}\right)$ $89.14 \mathrm{~g} \cdot \mathrm{mol}^{-1}=1.0402 ;{ }^{1} \mathrm{H}$ NMR $\left(\mathrm{D}_{2} \mathrm{O}, 25^{\circ} \mathrm{C}, 300 \mathrm{MHz}\right): \delta(\mathrm{ppm})=2.45$ $3 f(\mathrm{~s}, 3 \mathrm{H}, \mathrm{NMe}), 2.63\left(\mathrm{~m}, 2 \mathrm{H}, \mathrm{H}_{2} \mathrm{NN}(\mathrm{Me}) \mathrm{CH}_{2}\right), 2.80(\mathrm{~m}, 2 \mathrm{H}$ $\left.\mathrm{CH}_{2} \mathrm{NH}_{2}\right) ;{ }^{13} \mathrm{C}\left\{{ }^{1} \mathrm{H}\right\}$ NMR (DMSO $\mathrm{d}_{6}, 25^{\circ} \mathrm{C}, 75 \mathrm{MHz}$ ): $\delta(\mathrm{ppm})=39.2\left(\mathrm{CH}_{2} \mathrm{NH}_{2}\right), 49.9(\mathrm{NMe}), 64.3\left(\mathrm{H}_{2} \mathrm{NN}(\mathrm{Me}) \mathrm{CH}_{2}\right) ;{ }^{15} \mathrm{~N} \mathrm{NMR}$ (DMSO d $\left./ \mathrm{CD}_{3} \mathrm{NO}_{2}(50 / 50), 25^{\circ} \mathrm{C}, 50 \mathrm{MHz}\right): \delta(\mathrm{ppm})=20.0\left(\mathrm{CH}_{2} \mathrm{NH}_{2}\right)$, $63.4\left(\mathrm{NH}_{2} \mathrm{~N}(\mathrm{Me}) \mathrm{CH}_{2}\right), 91.9\left(\mathrm{NH}_{2} \mathrm{~N}(\mathrm{Me}) \mathrm{CH}_{2}\right) ;$ HRMS $\left(\mathrm{ESI}^{+}\right):[\mathrm{M}+\mathrm{H}]^{+}$ $\mathrm{m} / \mathrm{z}=90.1026$ (calcd.), 90.1032 (found), $[\mathrm{M}+\mathrm{Na}]^{+} \mathrm{m} / \mathrm{z}=112.0845$ (calcd.), 112.0856 (found), $[2 \mathrm{M}+\mathrm{H}]^{+} \mathrm{m} / \mathrm{z}=179.1979$ (calcd.), 179.1989 (found), $[2 \mathrm{M}+\mathrm{Na}]^{+} \mathrm{m} / \mathrm{z}=201.1798$ (calcd.), 201.1816 (found); IR (Golden gate, v $\left.\left(\mathrm{cm}^{-1}\right)\right)=3282(\mathrm{w}(\mathrm{b})), 2947(\mathrm{w}), 2880(\mathrm{w}), 2843(\mathrm{w}), 2791(\mathrm{w}), 1603(\mathrm{w})$, 1449 (w), $1361(w), 1326(w), 948(w), 877(w), 830(w), 761(m)$; DSC (Medium pressure Steel crucible, -50 to $400^{\circ} \mathrm{C}, 5^{\circ} \mathrm{C} / \mathrm{min}$ ): $\mathrm{T}_{\mathrm{b}}$ (onset) = $136^{\circ} \mathrm{C}, \mathrm{T}_{\mathrm{d}}$ (onset) $=223^{\circ} \mathrm{C}$; ISI (BAM, constant energy) $>50 \mathrm{~J}$.

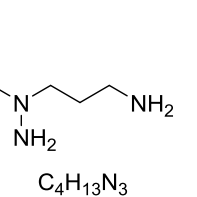

3-(1-Methylhydrazinyl)propan-1-amine (3g)

Compound prepared from 3-chloropropylamine hydrochloride $(2.00 \mathrm{~g}, 15.4 \mathrm{mmol})$ yielding $1.06 \mathrm{~g}$

$\mathrm{C}_{4} \mathrm{H}_{13} \mathrm{~N}_{3}$ $103.17 \mathrm{~g} \cdot \mathrm{mol}^{-1}$ $67 \%)$ as an orange liquid at R. T. $\left(18^{\circ} \mathrm{C}\right) .{ }^{1} \mathrm{H}$ NMR $3 \mathrm{~g}$ $\left(\mathrm{CDCl}_{3}, 25^{\circ} \mathrm{C}, 300 \mathrm{MHz}\right): \delta$ (ppm) $=1.65$ (quint., $2 \mathrm{H}$, $\mathrm{NCH}_{2} \mathrm{CH}_{2} \mathrm{CH}_{2} \mathrm{NH}_{2}, J=7.0 \mathrm{~Hz}$ ), 2.44 (s, 3H, NMe), 2.47 (t, $2 \mathrm{H}, \quad \mathrm{NCH}_{2} \mathrm{CH}_{2} \mathrm{CH}_{2} \mathrm{NH}_{2}, J=7.0 \mathrm{~Hz}$ ), 2.75 (t, $2 \mathrm{H}$, $\left.\mathrm{NCH}_{2} \mathrm{CH}_{2} \mathrm{CH}_{2} \mathrm{NH}_{2}, J=7.0 \mathrm{~Hz}\right) ;{ }^{13} \mathrm{C}\left\{{ }^{1} \mathrm{H}\right\} \mathrm{NMR}\left(\mathrm{CDCl}_{3}, 25{ }^{\circ} \mathrm{C}, 75 \mathrm{MHz}\right)$ : $\delta(\mathrm{ppm})=31.5\left(\mathrm{NCH}_{2} \mathrm{CH}_{2} \mathrm{CH}_{2} \mathrm{NH}_{2}\right), 40.5\left(\mathrm{NCH}_{2} \mathrm{CH}_{2} \mathrm{CH}_{2} \mathrm{NH}_{2}\right), 50.0(\mathrm{NMe})$, $61.3\left(\mathrm{NCH}_{2} \mathrm{CH}_{2} \mathrm{CH}_{2} \mathrm{NH}_{2}\right)$.

\section{General procedure for the synthesis of hydrazines $3 \mathrm{~h}$ and $3 \mathbf{i}$}

The Cbz-protected chloroalkylamine precursor (1eq, see SI for synthesis procedure details) was introduced under Argon into a $25 \mathrm{~mL}$ schlenk tube

and its temperature was maintained at $20^{\circ} \mathrm{C}$ by means of a cryothermostat. $\mathrm{MMH}$ (circa $8 \mathrm{eq}$ ) was then added and the reaction mixture was stirred overnight at $20^{\circ} \mathrm{C}$, after which it was neutralized by adding a saturated aqueous solution of $\mathrm{NaOH}$ (1.05eq). The aqueous phase was extracted with dichloromethane and the organic phases were collected, dried over $\mathrm{MgSO}_{4}$ and evaporated under reduced pressure leading to a pure compound.

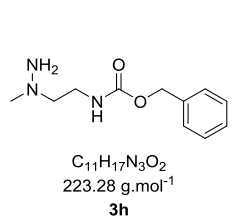

Benzyl (2-(1-methylhydrazinyl)ethyl)carbamate (3h)

Compound prepared from Benzyl (2chloroethyl)carbamate $(17.0 \mathrm{~g}, 79.6 \mathrm{mmol})$ yielding $17.39 \mathrm{~g}(97 \%)$ as a colorless liquid at R. T. $\left(33^{\circ} \mathrm{C}\right)$. ${ }^{1} \mathrm{H}$ NMR $\left(\mathrm{CDCl}_{3}, 25^{\circ} \mathrm{C}, 300 \mathrm{MHz}\right): \delta(\mathrm{ppm})=2.48(\mathrm{~s}$, $3 \mathrm{H}, \mathrm{NMe}$ ), 2.52 (t, 2H, MeNCH $\mathrm{CH}_{2} \mathrm{NHCO}_{2}, J=5.5 \mathrm{~Hz}$ ), 2.80 (s(b), $2 \mathrm{H}$, $\mathrm{NNH}_{2}$ ), 3.37 (q, 2H, MeNCH $\left.\mathrm{CH}_{2} \mathrm{NHCO}_{2}, J=5.5 \mathrm{~Hz}\right), 5.10$ (s, 2H, $\left.\mathrm{NHCO}_{2} \mathrm{CH}_{2}\right), 5.70\left(\mathrm{~s}(\mathrm{~b}), 1 \mathrm{H}, \mathrm{CO}_{2} \mathrm{NH}\right), 7.36-7.73\left(\mathrm{~m}, 5 \mathrm{H}, \mathrm{H}_{\text {aro }}\right) ;{ }^{13} \mathrm{C}\left\{{ }^{1} \mathrm{H}\right\}$ $\operatorname{NMR}\left(\mathrm{CDCl}_{3}, 25^{\circ} \mathrm{C}, 75 \mathrm{MHz}\right): \delta(\mathrm{ppm})=39.5\left(\mathrm{MeNCH}_{2} \mathrm{CH}_{2} \mathrm{NHCO}_{2}\right), 51.3$ $(\mathrm{MeN}), 60.9\left(\mathrm{MeNCH}_{2} \mathrm{CH}_{2} \mathrm{NHCO}_{2}\right), 66.7\left(\mathrm{CO}_{2} \mathrm{CH}_{2}\right), 128.1-128.2-128.6$ $\left(C_{\text {aro }}\right), 136.9\left(\mathrm{OCH}_{2} \mathrm{C}\right), 156.6(C=\mathrm{O}) ;{ }^{15} \mathrm{~N} \mathrm{NMR}\left(\mathrm{CD}_{3} \mathrm{NO}_{2}, 25^{\circ} \mathrm{C}, 50 \mathrm{MHz}\right)$ : $\delta(\mathrm{ppm})=64.9\left(\mathrm{NH}_{2} \mathrm{MMe}\right), 80.8(\mathrm{NHC}(\mathrm{O})), 90.8\left(\mathrm{NH}_{2}\right)$; HRMS $\left(\mathrm{ESI}^{+}\right)$ $[\mathrm{M}+\mathrm{H}]^{+} \mathrm{m} / \mathrm{z}=224.1394$ (calcd.), 224.1391 (found), $[\mathrm{M}+\mathrm{Na}]^{+} \mathrm{m} / \mathrm{z}=246.1213$ (calcd.), 246.1208 (found); IR (Golden gate, $\left.v\left(\mathrm{~cm}^{-1}\right)\right)=3326(\mathrm{w}(\mathrm{b})), 3033$ (w), 2948 (w), 2837 (w), 2793 (w), 1699 (s), 1599 (w), 1521 (m), 1454 $(\mathrm{m}), 1408(\mathrm{w}), 1329(\mathrm{w}), 1249(\mathrm{~s}), 1140(\mathrm{~m}), 1047(\mathrm{~m}), 1014(\mathrm{~m}), 907(\mathrm{w})$ $827(w), 774(w), 736(m), 697(s), 636(w), 608(w), 574(w), 538(w)$, $517(w), 491(w), 460(m)$

\section{Benzyl (3-(1-methylhydrazinyl)propyl)carbamate (3i)}

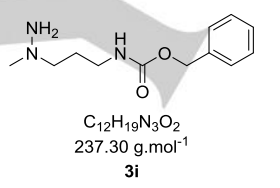

Compound prepared from Benzyl (3chloropropyl)carbamate (821.6 mg, $3.6 \mathrm{mmol}$ ) yielding $841.5 \mathrm{mg}(98 \%)$ as a yellow liquid at $\mathrm{R}$. T. $\left(33^{\circ} \mathrm{C}\right) .{ }^{1} \mathrm{H}$ NMR $\left(\mathrm{CDCl}_{3}, 25^{\circ} \mathrm{C}, 300 \mathrm{MHz}\right): \delta$ (ppm) $=1.74$ (quint., $2 \mathrm{H}, \mathrm{MeNCH}_{2} \mathrm{CH}_{2} \mathrm{CH}_{2} \mathrm{NH}$, $J=6.4 \mathrm{~Hz}), 2.46(\mathrm{~s}, 3 \mathrm{H}, \mathrm{MeN}), 2.50(\mathrm{t}, 2 \mathrm{H}$, $\mathrm{MeNCH} \mathrm{CH}_{2} \mathrm{CH}_{2} \mathrm{NH}, J=6.4 \mathrm{~Hz}$ ), 3.28 (q, $2 \mathrm{H}, \mathrm{MeNCH}_{2} \mathrm{CH}_{2} \mathrm{CH}_{2} \mathrm{NH}, J=6.4$ $\mathrm{Hz}), 5.09\left(\mathrm{~s}, 2 \mathrm{H}, \mathrm{CO}_{2} \mathrm{CH}_{2}\right), 5.48\left(\mathrm{~s}(\mathrm{~b}), 1 \mathrm{H}, \mathrm{CO}_{2} \mathrm{NH}\right), 7.29-7.36(\mathrm{~m}, 5 \mathrm{H}$, $\left.H_{\text {aro }}\right) ;{ }^{13} \mathrm{C} \quad\left\{{ }^{1} \mathrm{H}\right\} \quad \mathrm{NMR} \quad\left(\mathrm{CDCl}_{3}, \quad 25{ }^{\circ} \mathrm{C}, \quad 75 \quad \mathrm{MHz}\right): \delta \quad(\mathrm{ppm})=27.4$ $\left(\mathrm{N}(\mathrm{Me}) \mathrm{CH}_{2} \mathrm{CH}_{2} \mathrm{CH}_{2} \mathrm{~N}\right), 40.2\left(\mathrm{~N}(\mathrm{Me}) \mathrm{CH}_{2} \mathrm{CH}_{2} \mathrm{CH}_{2} \mathrm{~N}\right), 50.5$ (NMe), 61.2 $\left(\mathrm{N}(\mathrm{Me}) \mathrm{CH}_{2} \mathrm{CH}_{2} \mathrm{CH}_{2} \mathrm{~N}\right), \quad 66.6 \quad\left(\mathrm{CO}_{2} \mathrm{CH}_{2}\right), \quad 128.2-128.6 \quad\left(C_{\text {aro }}\right), \quad 136.9$ $\left(\mathrm{OCH}_{2} \mathrm{C}\right), \quad 156.6(\mathrm{C}=\mathrm{O}) ;{ }^{15} \mathrm{~N}$ NMR $\left(\mathrm{CD}_{3} \mathrm{NO}_{2}, 25{ }^{\circ} \mathrm{C}, 50 \mathrm{MHz}\right): \delta$ $(\mathrm{ppm})=66.6\left(\mathrm{NH}_{2} \mathrm{MMe}\right), 81.7(\mathrm{NHC}(\mathrm{O})), 90.9\left(\mathrm{NH}_{2}\right) ; \mathrm{HRMS}\left(\mathrm{ESI}^{+}\right):[\mathrm{M}+\mathrm{H}]^{+}$ $\mathrm{m} / \mathrm{z}=238.1550$ (calcd.), 238.1547 (found), $[\mathrm{M}+\mathrm{Na}]^{+} \mathrm{m} / \mathrm{z}=260.1369$ (calcd.), 260.1367 (found), [2M+Na] $]^{+} \mathrm{m} / \mathrm{z}=497.2847$ (calcd.), 497.2843 (found).

\section{Synthesis of 1-(2-azidoethyl)-1-methylhydrazine (4)}

\begin{tabular}{|c|c|}
\hline $\begin{array}{l}\mathrm{N}_{\mathrm{N}}-\mathrm{N}_{3} \\
\mathrm{~N}_{3} \mathrm{H}_{9} \mathrm{~N}_{5} \\
1373 \mathrm{~g} \cdot \mathrm{mol}^{-1} \\
\quad 4 \\
\text { e solutio }\end{array}$ & 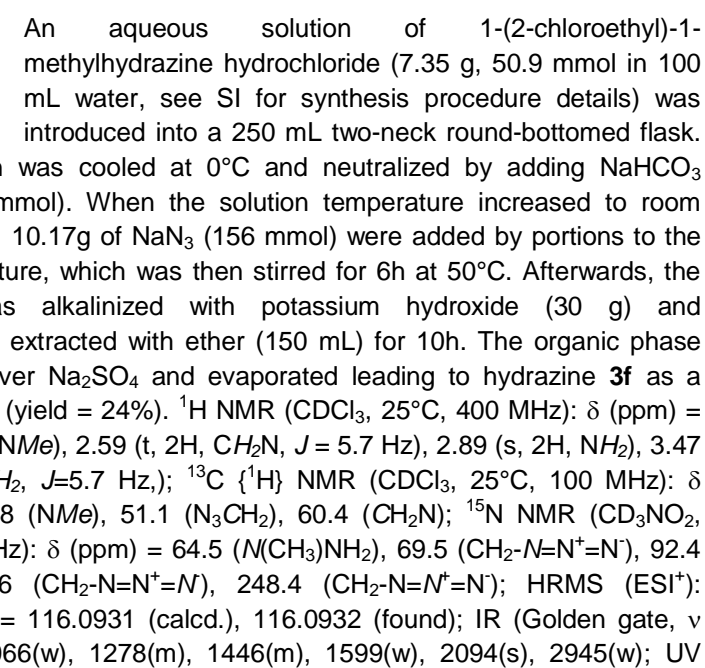 \\
\hline
\end{tabular}


$\left(\mathrm{Et}_{2} \mathrm{O}\right): \lambda_{\max }(\mathrm{nm})=244, \lambda_{2}(\mathrm{~nm})=302 ; \mathrm{DSC}\left(-50\right.$ to $\left.250^{\circ} \mathrm{C}, 5^{\circ} \mathrm{C} / \mathrm{min}\right): \mathrm{T}_{d}$ (onset) $=152.9^{\circ} \mathrm{C} ;$ ISI $($ BAM, constant energy) $>50 \mathrm{~J}$.

\section{Synthesis of 1-Azido-3-(1-methylhydrazinyl)propan-2-ol (5)}

$\mathrm{OH} \quad \mathrm{NH}_{2} \quad$ According to the synthesis procedure described above for hydroxyalkyl hydrazines $3 a$ to $3 e$, hydrazine 5 was $\mathrm{C}_{4} \mathrm{H}_{11} \mathrm{~N}_{5} \mathrm{O} \quad$ prepared from 1-Azido-3-chloropropan-2-ol (10.8 g $145.17 \mathrm{~g} \cdot \mathrm{mol}^{-1} \quad 79.7 \mathrm{mmol}$, see $\mathrm{SI}$ for synthesis procedure details) $5 \quad$ yielding $11.3 \mathrm{~g}(98 \%)$ as a pale yellow liquid at R. T. $\left(16{ }^{\circ} \mathrm{C}\right) . \mathrm{d}\left(16.3^{\circ} \mathrm{C}\right)=1.1493 ;{ }^{1} \mathrm{H}$ NMR $\left(\mathrm{D}_{2} \mathrm{O}, 25{ }^{\circ} \mathrm{C}, 400 \mathrm{MHz}\right): \delta$ $(\mathrm{ppm})=2.49(\mathrm{~s}, 3 \mathrm{H}, \mathrm{NMe}), 2.64\left(\mathrm{~d}, 2 \mathrm{H}, \mathrm{NCH}_{2} \mathrm{CHOHCH}_{2} \mathrm{~N}_{3}, J=7.1 \mathrm{~Hz}\right)$, 3.31 (dd, $1 \mathrm{H}, \quad \mathrm{NCH}_{2} \mathrm{CHOHCHHN}_{3}, J=6.7,13.0 \mathrm{~Hz}$ ), 3.43 (dd, $1 \mathrm{H}$, $\mathrm{NCH}_{2} \mathrm{CHOHCH} / \mathrm{N}_{3}, J=13.0,3.7 \mathrm{~Hz}$ ), 4.04 (ddt, $1 \mathrm{H}, \mathrm{NCH}_{2} \mathrm{CHOHCH}_{2} \mathrm{~N}_{3}$, $J=7.1,6.7,3.7 \mathrm{~Hz}) ;{ }^{13} \mathrm{C}\left\{{ }^{1} \mathrm{H}\right\} \mathrm{NMR}\left(\mathrm{CDCl}_{3}, 25^{\circ} \mathrm{C}, 75 \mathrm{MHz}\right): \delta(\mathrm{ppm})=52.5$ (NMe), $54.5\left(\mathrm{CH}_{2} \mathrm{~N}_{3}\right), 62.1\left(\mathrm{CH}_{2} \mathrm{~N}(\mathrm{Me}) \mathrm{NH}_{2}\right), 70.7(\mathrm{CHOH}) ;{ }^{15} \mathrm{~N} \mathrm{NMR}$ $\left(\mathrm{CD}_{3} \mathrm{NO}_{2}, 25^{\circ} \mathrm{C}, 50 \mathrm{MHz}\right): \delta(\mathrm{ppm})=65.9\left(\mathrm{CH}_{2} \mathrm{~N}=\mathrm{N}^{+}=\mathrm{N}^{-}\right), 67.1\left(\mathrm{NH}_{2} \mathrm{~N}\right)$ $91.9\left(\mathrm{NH}_{2} \mathrm{~N}\right), 207.2\left(\mathrm{CH}_{2} \mathrm{~N}=\mathrm{N}^{+}=N\right), 248.8\left(\mathrm{CH}_{2} \mathrm{~N}=\mathrm{N}^{+}=\mathrm{N}^{-}\right)$; HRMS $\left(\mathrm{ESI}^{+}\right)$: $[\mathrm{M}+\mathrm{H}]^{+} \mathrm{m} / \mathrm{z}=146.1036$ (calcd.), 146.1037 (found), $[\mathrm{M}+\mathrm{Na}]^{+} \mathrm{m} / \mathrm{z}=168.0856$ (calcd.), 168.0858 (found); IR (Golden gate, $\left.v\left(\mathrm{~cm}^{-1}\right)\right)=3313(\mathrm{w}(\mathrm{b})), 2946$ $(w), 2842(w), 2094(s), 1603(w), 1447(m), 1273(m), 1073(m), 1028$ $(w), 930(\mathrm{~m}), 900(\mathrm{w}), 873(\mathrm{w}), 823(\mathrm{~m}), 661(\mathrm{~m}), 555(\mathrm{~m}), 528(\mathrm{w}), 484$ (m), $471(\mathrm{~m}), 459(\mathrm{~m})$; UV $(\mathrm{EtOH}): \lambda_{\max }(\mathrm{nm})=223, \lambda_{2}(\mathrm{~nm})=283$; DSC (Medium pressure Steel crucible, -50 to $400^{\circ} \mathrm{C}, 5^{\circ} \mathrm{C} / \mathrm{min}$ ): $\mathrm{T}_{\mathrm{d}}$ (onset) = $139.9^{\circ} \mathrm{C}$; ISI (BAM, constant energy) $>50 \mathrm{~J}$

\section{Acknowledgements}

We gratefully acknowledge our sponsors, CNES, ArianeGroup, CNRS and Université Claude Bernard Lyon 1, for funding this work. J. E. thanks Université Claude Bernard Lyon 1 for his Ph.D. scholarship. Authors also thank Erwann Jeanneau (ISA, Lyon) for X-Ray measurement and crystal structure solving, Anne Baudoin (CCRMN, ICBMS, Lyon) for NMR analyses and the Centre Commun de Spectrométrie de Masse (ICBMS, Lyon) for mass spectrometry measurements.

Keywords: bishydrazines $\cdot$ functionalized hydrazines $\cdot$ scalable synthesis $\cdot$ monomethylhydrazine $\cdot$ energetic materials

[1] T. M. Klapötke, in High Energy Density Materials (Ed.: T.M. Klapötke), Springer Berlin Heidelberg, Berlin, Heidelberg, 2007, pp. 85-121.

[2] J. Eymann, PhD dissertation, Université Claude Bernard Lyon 1, 2020.

[3] L. Joucla, A. Dhenain, C. Darwich, J. Eymann, G. Jacob, FR3085376A1, 2020.

[4] J. Hogsett, V. Matthews, US003365338, 1968

[5] J. O. Edwards, R. G. Pearson, J. Am. Chem. Soc. 1962, 84 (1), 16-24.

[6] W. P. Jencks, J. Carriuolo, J. Am. Chem. Soc. 1960, 82 (7), 1778-1786.

[7] E. Buncel, I.-H. Um, Tetrahedron 2004, 60, 7801-7825.

[8] H. Böhme, F. Martin, Arch. Pharm. 1974, 307 (4), 272-277.

[9] L. Joucla, A. Dhenain, J. Eymann, FR3078968A1, 2019.

[10] B. Porath, P. Rademacher, R. Boese, D. Bläser, Z. Für Naturforschung B 2002, 57 (4), 365-376.

[11] A. Dhenain, $P h D$ dissertation, Université Claude Bernard Lyon 1, 2016.

[12] H. Delalu, C. Duriche, J. Berthet, P. Le Gars, FR2846646A1, 2004.

[13] E. G. Gharakhanian, T. J. Deming, Biomacromolecules 2015, 16, 1802 1806.

[14] a) http://www.bam.de; b) AFNOR, éd. Matériaux énergétiques de défense. Sécurité, vulnérabilité. Sensibilité au choc - Epreuve au mouton de choc BAM. NF T70-500 2007.
[15] Air force Manual, Liquid Propellant Handling, Storage, and Transportation, Vol. 161, United states, Dept. of the Air Force, 1973.

[16] V. Forquet, C. Miro Sabaté, H. Chermette, G. Jacob, E. Labarthe, H. Delalu, C. Darwich, Chemistry an Asian Journal 2016, 11(5), 730-744.

[17] T. Gilloux, C. Darwich, L. Joucla, G. Jacob, E. Labarthe, H. Delalu in proc. New Trends in Research of Energetic Materials 2014, pp. 662 671.

[18] M. J. Frisch, G. W. Trucks, H. B. Schlegel, G. E. Scuseria, M. A. Robb, J. R. Cheeseman, G. Scalmani, V. Barone, B. Mennucci, G. A Petersson, H. Nakatsuji, M. Caricato, X. Li, H. P. Hratchian, A. F. Izmaylov, J. Bloino, G. Zheng, J. L. Sonnenberg, M. Hada, M. Ehara, K. Toyota, R. Fukuda, J. Hasegawa, M. Ishida, T. Nakajima, Y. Honda, O Kitao, H. Nakai, T. Vreven, J. A. Montgomery Jr., J. E. Peralta, F. Ogliaro, M. Bearpark, J. J. Heyd, E. Brothers, K. N. Kudin, V. N Staroverov, T. Keith, R. Kobayashi, J. Normand, K. Raghavachari, A Rendell, J. C. Burant, S. S. Iyengar, J. Tomasi, M. Cossi, N. Rega, J. M. Millam, M. Klene, J. E. Knox, J. B. Cross, V. Bakken, C. Adamo, J. Jaramillo, R. Gomperts, R. E. Stratmann, O. Yazyev, A. J. Austin, R. Cammi, C. Pomelli, J. W. Ochterski, R. L. Martin, K. Morokuma, V. G. Zakrzewski, G. A. Voth, P. Salvador, J. J. Dannenberg, S. Dapprich, A D. Daniels, Ö. Farkas, J. B. Foresman, J. V. Ortiz, J. Cioslowski, D. J. Fox, Gaussian 09 Revision B.01.Gaussian Inc., Wallingford CT, 2010.

[19] J. W. Ochterski in Thermochemistry in Gaussian, Gaussian Inc., 2000 http://www.gaussian.com/g whitepap/thermo.htm.

[20] J. A. Montgomery Jr., M. J. Frisch, J. W. Ochterski, G. A. Petersson, J. Chem. Phys. 1999, 110(6), 2822-2827.

[21] a) V. Forquet, $P h D$ dissertation, Université Claude Bernard Lyon 1, 2012; b) V. Forquet, C. Darwich. G. Jacob, E. Labarthe, H. Delalu in proc. New Trends in Research of Energetic Materials 2013, pp. 586598.

[22] P. J. Linstrom, W. G. Mallard in NIST Standard Reference Database n69 (Eds.: NIST Chemistry Webbook), National Institute of Standards and Technology, Gaithersburg MD, 20899. http://webbook.nist.gov

[23] CRCNETBASE, (Eds.: Handbook of Chemistry and Physics online), Taylor \& Francis Group, LLC. http://www.hbcpnetbase.com/

[24] T. M. Donovan, C. H. Shomate, W. R. McBride, J. Phys. Chem. B 1960, 64(2), 281-282.

[25] D. D. Wagman, W. H. Evans, V. B. Parker, R. H. Schumm, I. Halow, S M. Bailey, K. L. Churney, R. L. Nuttall, J. Phys. Chem. Ref. Data 1982, 11, 1-407.

[26] a) S. Gordon, B. J. McBride, computer program for complex Chemical Equilibrium Calculations (CEC71) 1971, NASA SP-273; b) S. Gordon, B. J. McBride, CEC71 1988, NASA TM-100785; c) S. Gordon, B. J. McBride, CEC71 1994, NASA RP-1311.

[27] L. G. Cole, E. C. Gilbert, J. Am. Chem. Soc. 1951, 73, 5423-5427. 


\section{Entry for the Table of Contents}

Insert graphic for Table of Contents here. ((Please ensure your graphic is in one of following formats))

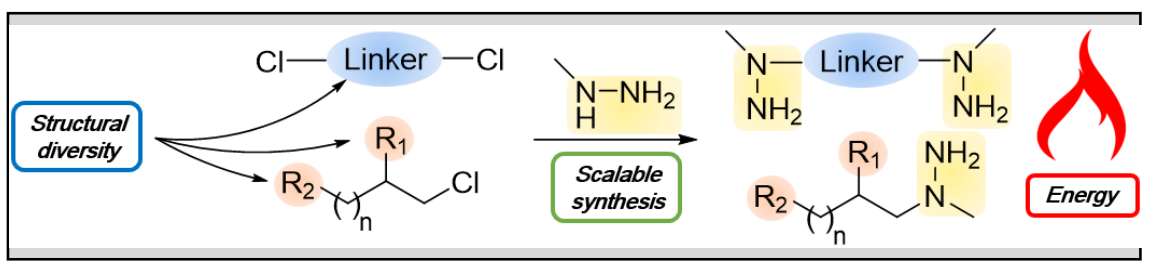

A versatile synthesis based on $\mathrm{MMH}$ and chloroalkyl substrates has been devised leading to seventeen new functionalized hydrazines and bishydrazines. These derivatives are key-ingredients for accessing higher polynitrogenated structures with energetic interest and tunable properties. Three of them (N/C ratio $\geq 1$ ) showed a low impact sensitivity, a good thermal stability and a specific impulse value similar to that of $\mathrm{MMH}$ bipropellant systems.

Institute and/or researcher Twitter usernames: ((optional)) 